\title{
ON THE PHYTOGEOGRAPHY OF CONIFERALES IN THE EUROPEAN CENOZOIC
}

\author{
DAVID K. FERGUSON \\ Division of Palaeobotany, Botanical Museum and Herbarium, State University, Utrecht (The \\ Netherlands)
}

(Received October 19, 1966)

\section{SUMMARY}

It has been shown that there were more coniferous genera to be found in Europe during the Tertiary than there are at the present-day. Some of the genera now occur only in America and the Far East. Many such genera were present in the Neogene of Europe and one of these, Tsuga, remained in Europe into the Late Pleistocene. Other genera found in Europe at the present-day had, in a number of cases at least, somewhat of a different distribution than now. In the present undertaking much use is made of results derived from pollen studies and it is suggested that pollen may be one of the major lines of evidence leading to a solution of certain phytogeographical problems.

\section{INTRODUCTION}

The first appearance of the conifers as a recognizable group can be traced back to the Late Palaeozoic. By the middle of the Mesozoic many, if not all, the major groups recognized within the living conifers appear to have been established and even a few present-day genera are recorded within the deposits of this age.

Along with the cycadophytes and possibly a few other gymnosperms, the conifers must have formed the overstorey in the Mesozoic forests. One might expect, therefore, that on the sudden expansion of the angiosperms at the beginning of the Upper Cretaceous that there might have been somewhat of a diminution in the number of conifer taxa. The number of described taxa, however, anything but diminishes-in fact, it seems to increase somewhat. It is possible that the actual part played by the conifers in the vegetation may have been reduced although it is hard to make any estimates of this. Depositional factors often exerting a particular affect within any given area tend to distort the true picture and add to the difficulties caused by possible differences in ecology from one area to another.

Tertiary rocks containing plant remains are found scattered over much of 
Europe and all the stratigraphical units are widely distributed. This is a helpful situation when it comes to examining the past geographical distribution of the Coniferae.

One finds when one plots the number of different types of conifers apparently attributable to living genera that there is a rise in the absolute number from the Paleocene up to the Miocene, after which there is a drop in the number. This could be a reflection of the evolution of living taxa within the Tertiary or, on the other hand, something to do with my sampling or a combination of the two. Out of the 454 European references consulted on this present occasion $170(37.5 \%)$ dealt with floras attributed by the original authors to the Miocene, $127(28 \%)$ to the Pliocene, $91(20 \%)$ to the Oligocene, 53 (almost $12 \%)$ to the Eocene and only 13 $(3 \%)$ to the Paleocene. In regard to the Pleistocene, which has been very thoroughly examined, the actual drop in numbers at the beginning of this period would appear to be a real one.

The number of genera attributable to one particular period is somewhat open to question. This is the result of uncertainties as to the precise age of one or two of the critical localities. Such uncertainties are bound to crop up when the plant remains are the only fossils to be found within the particular deposit. This leads to the possibilities of correlating deposits of different ages simply on the basis of a similar flora or pollen diagram and rejecting other possible correlations simply because the plant remains are different. Too little account is taken of possible ecological or geographical factors or the fact that similar plant successions can occur at different times. When insect, bivalve, fish or mammalian remains are present, as they sometimes are, these can be used for dating in conjunction with the plant remains. Age determinations based on faunas and floras are none the less fallible and one looks forward to the day when those fossil floras occurring between lava flows or volcanic ash can be more accurately dated using methods based on known rates of radioactive decay.

The following is a summary of some of the more significant conifer genera that appear to have been present in the Tertiary of Europe.

\section{ARAUCARIACEAE}

This family contains two recent genera. Both have been reported from the European Tertiary. Only Araucaria can be substantiated and the records of Agathis, which are mentioned in some of the older literature, appear to be misidentifications.

\section{Araucaria}

This genus with a disjunct distribution in South America, northeastern Australia and some islands to the north and east of Australia can be a remarkably 
difficult genus to recognize as a fossil. Although the large cones and their deciduous ligulate (appendage-bearing) scales generally cause no difficulty the vegetative organs, unless examined in great detail, could be misleading. Foliage attributed to Araucaria is particularly common in the Lower Tertiary, although it is found in the Upper Tertiary as well. It is only when one knows whether the leaves were arranged with their greater thickness radially or concentrically in relation to the axis of the shoot that one can pin down the fossil to a small number of genera then distinguishable on the basis of their cuticles. This requires that the fossil should be but little compressed, a requirement rarely fulfilled. Those twigs described from the Eocene of various localities in southern England by CHANDLER (1961a, pp.2328) and figured by her do appear to fulfil this condition enough to enable one to determine that the greatest thickness of the leaf was, at least in that case figured on her plate 12 , fig. 12 , concentrically rather than radially disposed in relation to the axis of the shoot. This and the cuticle tend to indicate that Araucaria was still present in the Lower Tertiary. Cones and cone-scales show that Araucaria or a related form was fairly common in the European Jurassic and Cretaceous (e.g., SEWARD, 1919), but there is still a lack of information as to its upper limit. The wingless non-aperturate pollen cannot really be used with any great success as a guide in this and other problems concerned in its distribution.

\section{CUPRESSACEAE}

As isolated organs, members of the Cupressaceae are often difficult to assign to a particular genus. Records of certain genera e.g., Actinostrobus, Widdringtonia, in the European Tertiary are consequently open to question. A revision of the fossils assigned to this family is badly needed.

\section{Cupressus}

This genus has a present discontinuous range in northern Africa, the eastern Mediterranean and Near East, the Himalayas and China, and in North America. In all but the seedlings the leaves are scale-like, which makes recognition difficult and one is faced with the problem of almost smooth, round, non-aperturate pollen. These and other characters go to make up a well-circumscribed genus, but as isolated organs this genus would be all but impossible to recognize were it not for the cone. This is an almost round body composed of a small number of scales, whose exterior form is polygonal. It can generally be distinguished from those of Chamaecyparis in being larger when mature. Such cones have been found in various parts of Europe throughout the whole of the Tertiary, although their true affinity seems to have eluded a number of authors. The cone described as Callitris brongniartii by RASKY (1958, pl.16, fig.8) appears to be a Cupressus and a re-examination 
of some of the material ascribed to Sequoia (KRÄUSEL, 1940, p.449, pl.3e; MÄGDEFRAU, 1956, p.308, fig.295) might well reveal that these should be attributed to Cupressus. Records of this genus outside its present range indicate that its distribution may, at one time, have been more or less continuous.

\section{Juniperus (including Arceuthos)}

This genus ranges from ca. $70^{\circ} \mathrm{N}$ to $20^{\circ} \mathrm{N}$, being widespread in Eurasia and North America. The usually fleshy "fruit" distinctive enough among the conifers would not be distinguishable from the fruit of certain angiosperms were it found fossil. The pollen is of a "cupressoid" type, round and inaperturate and having a more or less smooth exine. Part of the genus has scale-like leaves when mature (section Sabina), while the other section (section Oxycedrus) has triangular leaves often arranges in whorls. The scale-like leaves of section Sabina make it difficult to recognize these species simply from its vegetative shoots and even the triangular leaves in whorls are not sufficient to distinguish this from other genera. Often, however, these leaves are attached to the axis of the shoot by a form of ball-andsocket joint, this being characteristic of many species of Juniperus and including $J$. drupacea (often segregated into the genus Arceuthos). Leaves of this type have been found in the Miocene of Bourboule near Mont Dore, in France (Glangeand and Marty, 1936, p.21, pl.A, fig.2, 3) and at Stare Gliwice in Poland (SzAfer, 1961, pl.8, fig.11-17). Other compressions with triangular leaves apparently in whorls and having a cuticle resembling certain species of Juniperus (and apparently different from that of Arceuthos) have been found in the Pliocene of Willershausen in Germany (STRaUs, 1952, p.31, e.g., pl.17, fig.3).

\section{Tetraclinis}

This genus is now restricted to the north coast of Africa, to near Carthagena in Spain, and to the Maltese Islands (Fig.1). It is related to Callitris, a Southern Hemisphere genus and it is only in recent taxonomic procedure that it has been separated from Callitris sensu latu, covering what are now classified as three distinct genera: Callitris sensu strictu, Actinostrobus and Tetraclinis. The geographical range of these taxa was one of the arguments favouring this separation. The unwinged, inaperturate pollen of Tetraclinis is no help in separating this genus from a host of other Cupressaceae and the seed unfortunately resembles that of Agathis alba. The vegetative shoots with their groups of four closely appressed leaves do enable one to separate this genus from other genera within the Cupressaceae and Callitris and Actinostrobus in particular (both of these latter genera have leaves in whorls of three). The four-(rarely more) valved "fruit" adds additional weight to the determinations when found attached to the twigs. Remains of this genus found in the Tertiary of Europe show that this genus once extended to the 


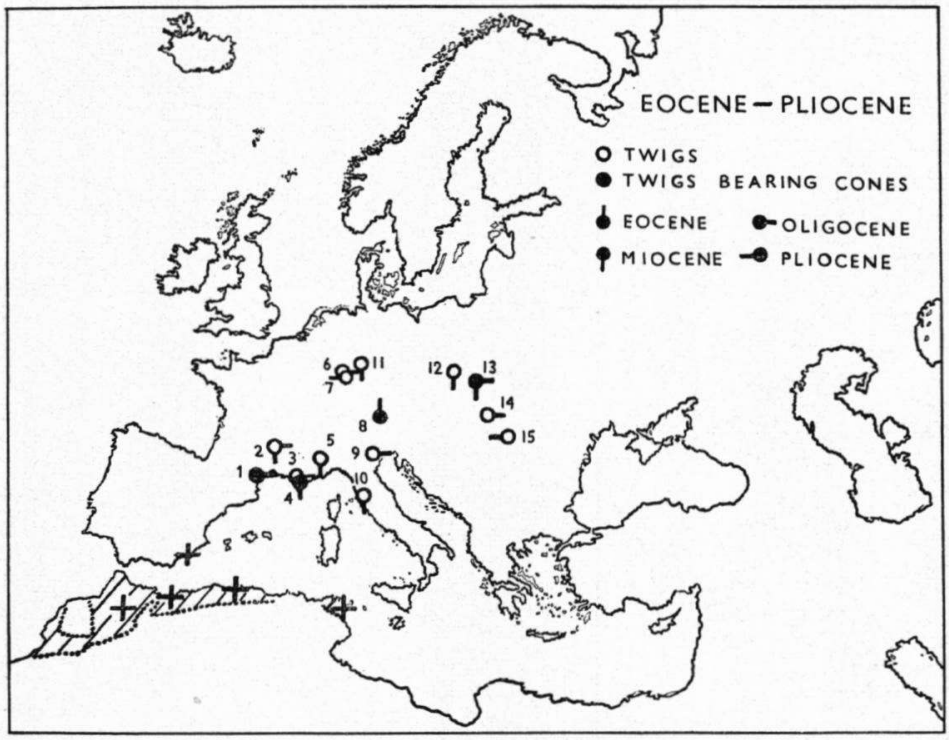

Fig.1. Tetraclinis, its past and present distribution.

\section{Past distribution}

$I=$ De SAPORTA (1865, pp.39-40, pl.1, fig.6); 2 = Boulay (1899, p.82); 3 = De SAPORTA (1862, pp.209-210, pl.3, fig.1, 1873, p.14; 1888, pp.38-40, pl.3, fig.6-8, pl.5, fig.12); 4 = DE SAPORTA (1863, pp.31-33, pl.3, fig.2); 5 = Sismonda (1865, p.403, pl.4, fig.3, 4); 6 = VoN ETTINGSHAUSEN (1868, p.825); 7 = ENGelHARdT and KINKELIN (1911, p.190, pl.23, fig.5, e.g., 5d); $8=$ VoN Ettingshausen (1851, pp.34-35, pl.5, fig.7-35); $9=$ PrinciPI (1926, pp.22-24, pl.2, fig.1); $10=$ Berger (1957, p.10, pl.1, fig.9); $11=$ Engelhardt (1902, p.259, pl.1, fig.21, 22); $12=$ Szafer (1961, p.28, pl.7, fig.7, 8); 13 = ZABLOCKI (1928, pp.188-189, pl.8, fig.10-17a); 14 = VON ETTINGShausen (1853, pp.790-791); 15 = GivulesCu (1960, p.38, 1962, p.136, fig.35-36).

\section{Present distribution}

This is shown in shading (based on JAHANDIEA and MAIRE, 1931; and BoRO, 1927) with those specimens examined by the present author in the Edinburgh Herbarium shown as crosses.

north of its present range. Whether it occurred in Africa in the past is a matter for speculation for few investigations appear to have been undertaken in this part of the world. Undoubted records range from the Eocene up to the end of the Pliocene, when it disappeared from Europe. It would appear that at the present-day its range is further diminishing for place-names like Ghar-ghar and Ghar-ghur on Malta in areas where Tetraclinis is no longer found would indicate its presence there in the none too distant past (BORG, 1927, p.94).

Vegetative shoots bearing scale-like leaves have been assigned to a number of genera within the Cupressaceae, based on differences in the shape and arrangement of these leaves. Sometimes the particular species described appears to be well-circumscribed, e.g., Libocedrus salicornioides, which has been found in a number of European localities beginning with the Eocene or earlier and ending in the Plio- 
D. K. FERGUSON
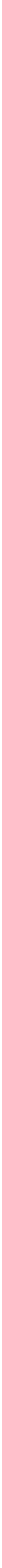
cene. The vegetative shoots have been assigned to Libocedrus on the particular arrangement of the leaves and it is generally assumed to have been related to Libocedrus decurrens found in western North America at the present-day. The fossil is noted as having considerably larger vegetative shoots, but this in itself has not been considered as sufficient evidence for making it the basis of an extinct genus. When one comes to examining the leaves, having first soaked them in peroxide solution to decompress them, one finds, however, that the four leaves making up a group are laterally fused, almost along their entire length, whereas in those genera superficially resembling the fossil an inner partially fused pair of leaves is surrounded by a pair of imbricate leaves free to the base. On this character difference and that of the size of the vegetative shoots, one must, according to the author, follow SEWARD (1919) in placing this species in the somewhat artificial genus Cupressinocladus. This is purely a taxonomic change, but its affect is felt in other fields, one of which is historical plant geography. One can no longer say that Libocedrus once had a larger geographical range than it does at present and quote these fossils as evidence. Instead, at least as far as Libocedrus is concerned, one must look for other lines of evidence.

Fig.2. The distribution of Abies within the European Tertiary.

\section{A. Eocene-Oligocene}

$I=$ Pflug (1959, p.162); 2 = Pflug (1959, p.162); 3 = Pflug (1956, p.418, 1959, p.162); $4=$ Pflug (1959, p.162); 5 = Helal (1958, p.427); 6 = Samuel and Snopková (1962, pp.73, 77); 7 = Grossheim and GladKova (1951, pl.1-Oligocene or Miocene); 8 = AbUziarova (1955, p.127, pl.1, fig.7, 1958, p.150).

\section{B. Miocene}

$l=$ Glangeand and MARTY (1936, p.21, pl.A, fig.1); $2=$ MARTY (1931, p.183, pl.9, fig.5); $3=$ FirTiOn (1958, p.276, pl.6, fig.1); $4=$ ZeidleR (1938, p.200); $5=$ RUdOLPH (1936, pp.305, 307); 6 = MAZANCOVÁ (1962, p.170); 7 = SNOPKOVÁ (1961, pp.220, 222); 8 = SNOPKOVÁ (1961, pp.218, 222); $9=$ MilaKovic (1960); $10=$ WeYland et al. (1958, p.80); 11 = OsZaSt (1960, p.13, pl.4, fig.4, 5); Szafer (1961, pp.17-18, pl.4, fig.1-3, 7-8, 15); 12 = PlanderovA (1963); $13=$ ShCheKINA (1958, pp.64-65); $14=$ ShCheKINA (1956, p.45, 1957, p.37); $15=$ ShChEKINA (1957, p.37); 16 = SHCHEKINA (1962, fig.46).

\section{Pliocene}

$I=$ Pflug (1959, p.162); $2=\operatorname{JuX}(1960$, pp.18, 21, pl.2, fig.8); $3=\operatorname{Dinz}(1965$, p.375); $4=$ LaUReNT and MARTY (1927, pp.67-68, pl.15, fig.8); $5=$ FirTION (1946, pp.512-513); 6 = Pons (1964, pp.558-559); 7 = Ballesio and MeON-Vilain (1965, p.16); 8 = FlorschüTZ and VAN SOMEREN (1950); $9=$ RUdDOLPH (1936, p.311); LeschIK (1956, p.34, pl.15, fig.9); $10=$ Mäbler (1939, pp.19-21, pl.1, fig.10-17); 11 = LoNa (1962, p.90); $12=$ Thomson and PfLug (1953, p.68, 1.5, fig.6-7); 13 = LeschIK (1954, pl.1, fig.8); 14 = RUdOLPH (1936, p.267); 15 = MeYER (1956, p.123, table 4); 16 = WeYland et al. (1958, p.77); $17=$ LöhNert (1961, textpl.25); $18=$ Pacltová (1963, pl.6); 19 = SNOPKOVÁ (1960, p.192, table 1); 20 = DoKTOROWICZ-HrEBNICKA (1957a); 21 = DoKTorowicz-HrebnicKa (1957a); 22 = Szafer (1954, fig.9); 23 = NAGY (1959, p.414); $24=$ Givulescu (1962, p.133, pl.25, e.g., fig.10); 25 = Pantić and Nicolić (1956, p.71); $26=$ Weyland and Pflug (1957, p.100); Weyland et al. (1958, p.79); 27 = Shatilova (1962, p.897). 


\section{PINACEAE}

\section{Abies (Fig. 2)}

This somewhat disjunctly distributed genus from the Northern Hemisphere is mainly confined to the more southern part of Europe where it occurs in mountainous regions. The fairly large seed is of the general type found within the Pinaceae and is, in consequence, of no value in tracing the past distribution of the genus. The cone, too, which may be confused with genera such as Cedrus has to be discounted as a valid means on which to base its past record. The leaves of the genus are somewhat variable in shape and some of these have a notched apex, a feature unfortunately found in a number of other genera as well, e.g., Tsuga and Pseudotsuga. What is found in some species of Abies and is confined to the genus is the presence of a swollen base to the leaf. It is the occurrence of such leaves that has been recorded on the present maps. The pollen grain is large and winged, differing apparently from other genera, e.g., Keteleeria in having an exine which reaches the thickness of 6.5-11 $\mu$ proximally. Pollen resembling that of Abies has been found in the U.S.S.R. in the Lower Cretaceous (PokrovsKaYA and STRL'MAK, 1964) and the Upper Cretaceous-Lower Palaeogene transition (BratTseva, 1962) and throughout the Tertiary there is a continuous European record of the genus. The Eocene, Pliocene and Pleistocene records of pollen of this type in Iceland (Pflug, 1956, 1959; Jux, 1960) might suggest that the genus once had a complete range between Europe and North America. During the Pleistocene it was apparently present in the greater part of southern Europe and in the early part of the Holocene (just after Picea had firmly established itself) it became well-represented in most pollen diagrams. With the increase in the numbers of dicotyledons later on in the Holocene its numbers tended to fall off.

\section{Cathaya}

At the time when this Chinese genus was first described (CHUN and KuANG, 1958) the authors assigned to the genus a Pliocene cone formerly described as Keteleeria loehri (ENGELHARDT and KINKELIN, 1911). This transfer has been queried by FLORIN (1963, p.242). Since then two more European species have been described from Pliocene sediments east of the Black Sea (Svechnikova, 1964). One of these, Cathaya europaea, is based on a cone similar to that of the living species $C$. nanchuanensis and the other, Cathaya abchasica, on leaf fragments and cuticles. This latter species is compared by Svechnikova with the other living species, $C$. argyrophylla. The appearance of the leaf fragments is a poor guide as to the affinity of the fossil, but the cuticle with its somewhat angular stomata is similar to that of Cathaya. The pollen of Cathaya is fairly distinctive and should result in further information concerning the past distribution of the genus. 


\section{Cedrus}

This genus with its discontinuous distribution in the Himalayas, northern Africa, Turkey, Cyprus and the Lebanon is found at the present-day at altitudes of from 3,700-6,000 ft. and above (Fig.3). Its seed is like those of many species of Abies. The four-sided leaves are arranged in whorls and are obviously separable from other genera in a living or herbarium state. When it comes, however, to fossils there is a possibility of confusing it with, for example, Pseudolarix unless the fossil is sectioned or cuticles prepared. The pollen grains have a corpus of less than $75 \mu$ in breadth which should help distinguish it from Picea and differ from Pinus in having an internal ornamentation of the bladders which merges gradually into that of the corpus. Pollen resembling that of Cedrus has been found in the Jurassic and Cretaceous in the Urals (PAPYLOV and Bronnikova, 1961, p.99; Zharkova, 1961) and also in other parts of the U.S.S.R. (BolkhovitinA, 1956; PokrovsKAYA and Stel'maK, 1964) and during the Palaeogene it was to be found in Asia and America as well as in Europe. Cedrus pollen is found right into the Pliocene of Oregon (GRAY, 1964), which would indicate that its present restricted range is something of the comparatively recent past. It is recorded from the top of the Pliocene and in the First Interglacial in the Kashmir Valley of India (PURI, 1957; VISHNU-MITTRE et al., 1963) in an area where it still persists. It was in the Lower Pleistocene that its former widespread distribution throughout Europe became restricted to the more southern parts and is then recorded from North Africa. Whether it had occurred in North Africa prior to this time is uncertain for there appears to be little palynological literature published on the Tertiary from this part of the world. The same is true of Turkey and the Near East and so one cannot be sure if its occurrence there at the present-day is a development within the recent past or whether it has been in the area since the Tertiary. From the diagram published by LoNA $(1950, \mathrm{pl} .3)$ it would appear that Cedrus was absent from the north of Italy by the end of the Günz Glaciation, although it is possible that it hung on somewhat longer in more southern latitudes. Pons $(1964$, p.559) considered that the majority of the Cedrus grains which he encountered in his study of Pliocene deposits just north of Valence in southern France could be referred to the species (or subspecies) occurring in northern Africa at the present-day, although some could be referred to $C$. brevifolia (Cyprus and Sîr in the Lebanon at present) or C. libani (subsp. libani) now found in Turkey, Syria and the Lebanon. The author has gone through a number of articles illustrating the Cedrus pollen grains found in the Lower Pleistocene of Italy to see whether it was possible to assign the illustrations to one or a number of the species. The results obtained by following AYTUG (1961), who described the pollen of the four major taxa within the genus, were contradictory. Either this is the result of a poor correlation of the characters in the first place resulting either from the limited sample with which Aytug worked or from the different techniques employed by the varigurs authors in the preparation 


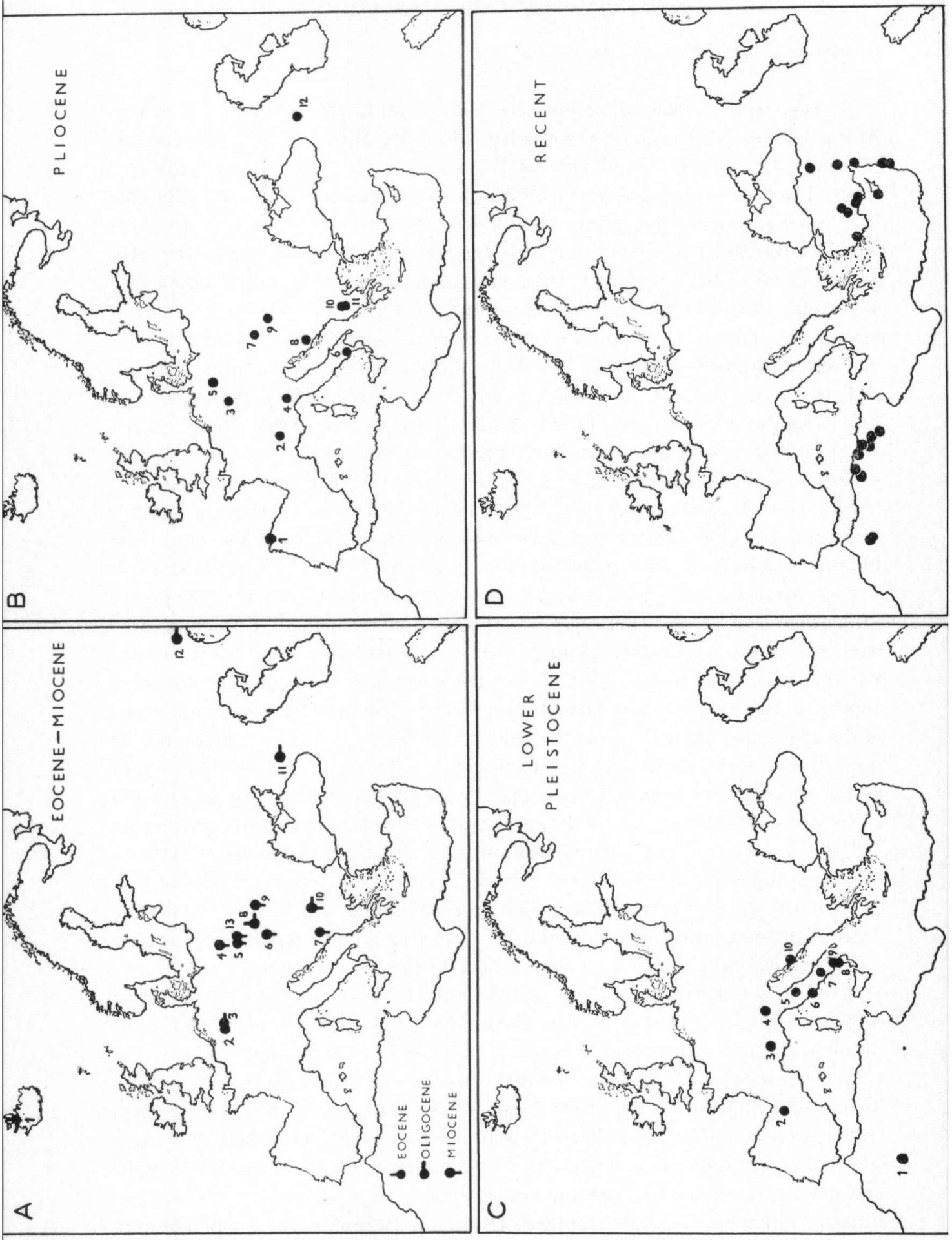

Palaeogeography, Palaeoclimatol., Palaeoecol., 3 (1967) 73-110 
of their pollen samples. Alternatively it may be taken as a pointer to the comparatively recent differentiation of the taxa within the genus. The present restricted distribution of the genus in northern Africa is, it should be added, a feature of the none too distant past for at the beginning of the Last Interpluvial, Cedrus, along with a number of other genera, invaded the whole of the central Sahara (QuÉzEL, 1960, p.358). The occasional record of Cedrus pollen in the uppermost part of the Holocene in some parts of western Europe, e.g., Le Moura at the western end of the Pyrenees (OldField, 1962, p.213) would appear to be due to its subsequent reintroduction by man as timber, for which purpose it is still grown in some part of Spain.

\section{Keteleeria}

This is a genus found only in the Far East at the present-day. Its cones with their imbricate scales and its leaves, even when found attached to their parent shoots, may be confused with a number of other members of the Pinaceae. The seed too is of the general type found within the Pinaceae so that there only remains the pollen which may be of some use in tracing the fossil history of the genus. The pollen of Keteleeria is very similar to that of Abies in overall shape and size and appears to differ from Abies only in the proximal thickness of the exine, which in Keteleeria is some $3-4 \mu$ thick. In $A b i e s$, as already noted, the proximal exine

Fig.3. The present distribution of Cedrus and its distribution in the Cenozoic.

\section{A. Eocene-Miocene}

$I=$ Pflug (1956, p.418); 2 = Von der Brelie and Wolters (1958, p.475); 3 = Helal (1958, p.427); 4 = KREMP (1950, p.61, pl.4, fig.23, 25-26); 5 = MAZANCOVÁ (1962, p.170); 6 = SNOPKovÁ (1961, p.218, pl.4, fig.3); 7 = WeYLAND et al. (1958, p.81); $8=$ SAMUEL and SNOPKOvÁ (1962); $9=$ ShCheKINA $(1958$, pp.64-65); $10=\operatorname{Givulescu}(1962$, p.134); $11=\operatorname{Kozyar}(1957$, p.301); 12 $=$ Abuziarova (1955, p.127, pl.1, fig.9, 1958, p.150); 13 = Macko (1957).

\section{B. Pliocene}

$1=$ NonN and Medus (1963, p.62-possibly Upper Miocene); $2=$ Pons (1964, p.559); $3=$ LeschiK (1956, p.34, pl.16, fig.10); 4 = LONA (1962, p.90); $5=$ LeSCHIK (1954, pl.1, fig.13); $6=$ LöhNert (1961, textpl.25); 7 = SNOPKová (1960, p.192, table 1); $8=$ Pantí́ and Bešlagić (1964); $9=$ Nagy (1959, p.414); $10=$ Weyland et al. (1958, p.79); $11=$ Weyland and Pfluo $(1957$, p.100); 12 = ShatILova (1962, p.897).

\section{Lower Pleistocene}

$I=$ Beucher (1963); 2 = H. Remy (in: WoldSTedT, 1958); 3 = Lerol-Gourhan (1961, pp.245246); 4 = LoNA (1950, pl.3); 5 = PAganelli (1960, p.603); 6 = FollierI and NAPOleone (1964); 7 = RicciardI (1963, p.868); 8 = LöHNERT (1961, textpl.28-29); LONA and RiCCIARDI (1961a); $9=$ LöhNerT (1961, textpl.25); $10=$ SERCELJ $(1965$, pl.1).

D. Recent

Data from Davis (1965), MAIRE et al. (1952), Post and Dinsmore (1932) and a number of specimens examined in the Edinburgh Herbarium. 


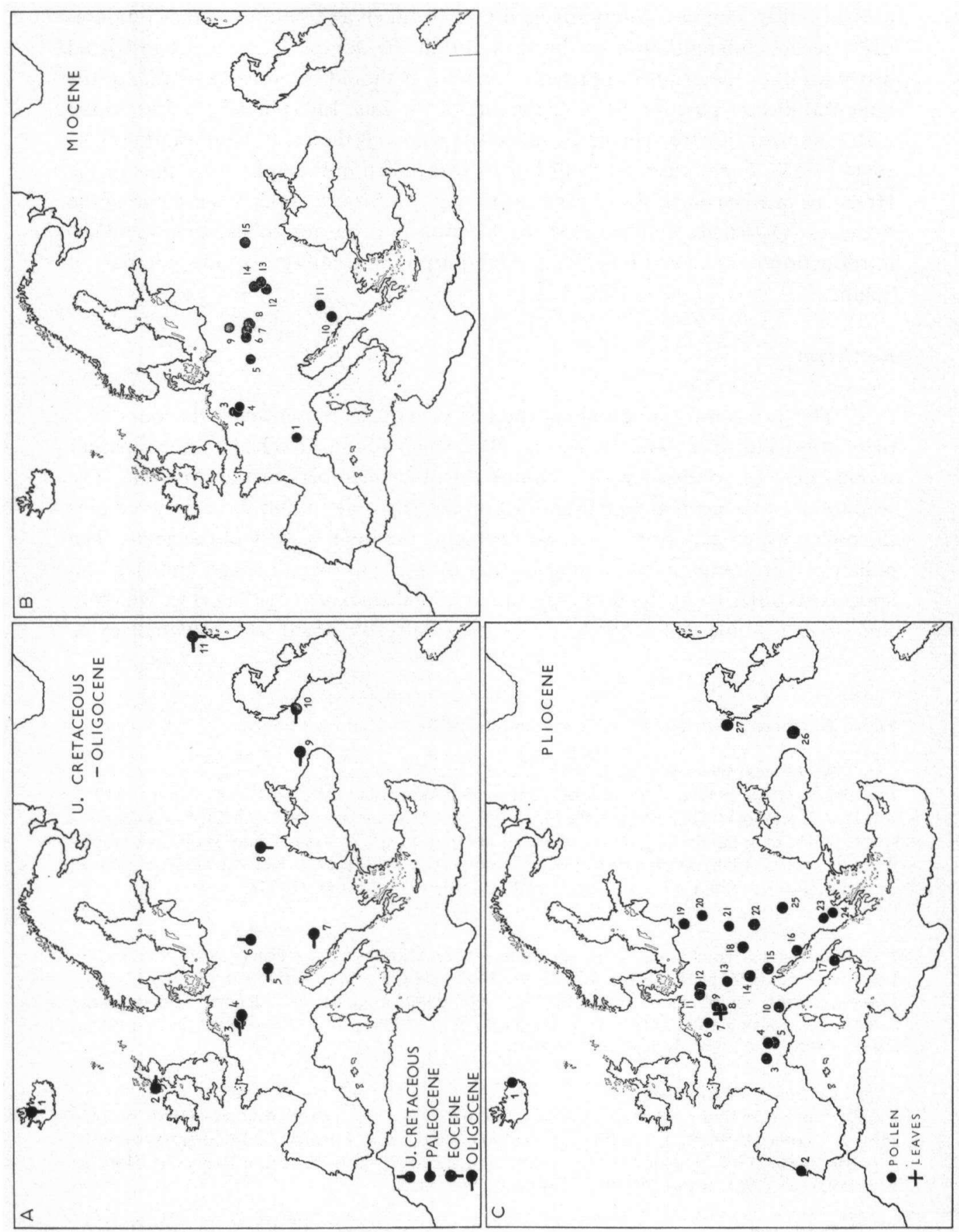


apparently reaches a thickness of 6.5-11 $\mu$ in all cases. Should this distinction be found to break down when a detailed examination of the pollen of the recent species of these two genera is undertaken then not only will the records of Keteleeria have to be re-examined but also the majority of those of Abies. Keteleeria pollen has apparently been identified from Lower Cretaceous deposits in the U.S.S.R. (Pokrovskaya and Stel'mak 1964, pl.55, fig.6, 7) and it has even been recorded from the Jurassic by Murachovskaya (1956). Pollen attributed to the genus has been found in European deposits ranging from the Eocene into the Lower Pleistocene. Since various authors have had their own opinion as to the distinction between the pollen of Keteleeria and Abies, the present author has had to restrict himself to the figured references. Sometimes, as in the case of their supposed occurrence in the Pliocene of Willershausen (FranTZ, 1961, p.427, pl.2, fig.2) and the Oligocene-Miocene boundary at Mydlovary, Czechoslovakia (PacltovA, 1958), the photograph does not show the critical feature and in others the record needs to be reconsidered, e.g., PAClTOVÁ and ŽERT (1958, p.351; Oligocene of Czechoslovakia); LeschiK (1954, pl.1, fig.14; Upper Pliocene of Germany); Paganelli (1962; interglacial of Italy); Stachurska (1960, p.283; interglacial of

Fig.4. The pre-Pleistocene distribution of Picea in Europe.

A. Upper Cretaceous-Oligocene

$I=$ PrLug (1956, p.418); 2 = Simpson (1961, pp.427-428, pl.6, fig.1-4, pl.7, fig.1-2, pl.8, fig.1); $3=$ Von Der Brele and Wolters (1958, p.475); 4 = Helal (1958, p.427); Thiergart (1958, p.448, pl.1, fig.16); Holtz (1962, p.27); 5 = PAClTová (1958, p.125-boundary Upper OligoceneLower Miocene); 6 = MACKo (1963, p.10, pl.1, fig.1); 7 = WEYLAND et al. (1958-boundary Upper Oligocene-Lower Miocene); $8=$ ShCHEKINA (1958); $9=\operatorname{KozYaR}(1957$, p.301); $10=$ Grossheim and Gladkova (1951, pl.1-Oligocene or Miocene); 11 = Abuziarova (1958, p.150).

\section{B. Miocene}

$I=$ FirTiON (1958, p.276, pl.6, fig.5-6); $2=$ D. Ferguson (unpublished, 1966); $3=$ MANTEN (1958, p.467); $4=$ THOMSON and ReIN (1949, p.109); $5=$ RUdOLPH (1936, pp.294, 305, 307); $6=$ Mazancová (1962, p.169); 7 = Macko (1959, pl.2, fig.1-4); 8 = Macko (1957); Oszast (1960, p.15, pl.5, fig.1-2); $9=$ KREMP (1950, p.61, pl.4, fig.18); $10=$ WeYLAND et al. (1958, p.80); $11=$ Weyland et al. (1958, p.80); $12=$ ShCheKINA (1958, pp.64-65); $13=$ ShCheKINA (1957, p.38); $14=$ ShChekina $(1956$, p.45, 1957, p.38); 15 = ShCHEkINA $(1962$, fig.48).

\section{Pliocene}

$l=\mathrm{Jux}(1960$, pl.2, fig.7); 2 = Diniz (1965, p.375); 3 = FirTion (1946, pp.512-514); $4=$ Ballesto and Meon-Vilain (1965, p.16); $5=$ Pons (1964, pp.560-561); $6=$ ZaGWIJN (1960, p.63); 7 = MülleR-STOLl (1938, pp.396-398, pl.9, fig.8, 9, pl.11, fig.2-4); $8=$ RUDOLPH (1936, p.311); LeschiK (1956, p.34, pl.16, fig.1); $9=\operatorname{LESCHIK}(1952$, fig.4); $10=$ LoNA (1962, p.90); $11=$ Thomson and Pflug (1953, p.68); $12=$ LeschIK (1954, pl.1, fig.17-18); $13=$ RudolPH (1936, p.267); 14 = MeYer (1956, p.123, pl.4); 15 = WeYland et al. (1958, p.77); 16 = Pantić and BeŠlaGić (1964); 17 = LöHNERT (1961, textpl.25); 18 = SNOPKOvá (1960, p.192, table 1); 19 = DokTorowicz-Hrebnicka (1957a); 20 = DokTorowicz-HrebnicKA (1957a); $21=$ Szafer (1954, fig.9); 22 = NAGY (1959, p.414); 23 = Pantić and Nicolić (1956, p.71); $24=$ Weyland and Pflug 1957, p.100); Weyland et al. (1958, p.79); 25 = Grvulescu (1962, p.134); $26=$ Shatilova $(1962$, p.897); $27=$ VRONSKII $(1963$, p.935). 
Poland). All the published Tertiary records which appear to be authentic (FIRTION, 1958, p.275, pl.6, fig.6; Oszast, 1960, p.16, pl.6, fig.5; MAI, 1964, p.12, pl.1, fig.18) are from the Miocene. The author has, however, seen what appears to be a good example of Keteleeria in an unpublished paper (W. Krutzsch and R. Vanhoorne, 1966) dealing with the Eocene of Belgium.

\section{Larix}

This largely North American and Asian genus has a somewhat disjunct distribution in Europe at the present-day. The large round inaperturate pollen grain is one which is unique among the recent conifers "native" to Europe. When one is dealing with the Tertiary, however, one has to guard against the possibility of similar pollen being that of Pseudotsuga. Both Larix and Pseudotsuga have been recorded as macrofossils from the Upper Tertiary of Europe. Wood remains assigned to Piceoxylon pseudotsugae are generally considered to belong to Pseudotsuga, but one cannot rule out the possibility that such wood could be that of Cathaya. Leaves and cone-scales have also been assigned to Pseudotsuga (STEFANOFF, 1930; ZALEWSKA, 1961), although such records are not nearly as common as those of Larix. At present it is not certain whether Pseudotsuga was present in the European Tertiary and it is possible that much, if not all, of the pollen referred to as Inaperturopollenites magnus R. Potonit is that of Larix. Such pollen is to be found in the European Cretaceous and Cenozoic.

\section{Picea (Fig. 4)}

This is a genus found at the present-day widely distributed north of latitude $20^{\circ} \mathrm{N}$. In Europe it is common in the northeast, being only recently planted in the northwest and rare in those regions bordering on the Mediterranean. Although one may be safe enough in attributing certain Pleistocene cones with imbricated cone-scales to Picea there is a great danger when one is working in Tertiary deposits of confusing this with other genera, many of which are now restricted to the Far East. The seed is of the general type found within the Pinaceae. Isolated leaves, even when examined for cuticles, are difficult to assign unless a cross-section shows that the leaf was four-sided (a feature of Picea section Eupicea), in which case one has only to distinguish between this and the genus Cedrus-a relatively easy task. The greatest asset the palaeobotanist has is the pollen. This is a large-winged grain (the corpus is more than $70 \mu$ in breadth) with a thin proximal exine and an internal ornamentation of the bladders, which merges gradually into that of the corpus. The bladders are hardly separated or even slightly overlapping, which feature, along with its size, should distinguish it from Cedrus pollen. Pollen said to be that of Picea has been found in the Jurassic of Srednem in the Urals (PAPYLov and Bronnikova, 1961, p.99) and is recorded by Bolkhovitina (1956) and Pokrovs- 
KAYA and Stel'MAK, (1964) from other Mesozoic deposits in the U.S.S.R. However, one must treat such records with caution, since the pollen may well be that of one of the many now extinct genera. In Europe and other parts of the Northern Hemisphere it was widespread during the Tertiary (especially in what appear to have been the temperate zones) and it appears to have undergone somewhat of a reduction in area only within the comparatively recent past (Pleistocene and Holocene). During the Ice Age Picea was found in many parts of southern Europe, although pollen diagrams from the Pleistocene of Padul in the southeast of Spain indicate that it was never present in this part during that time and it only comprises from $0-2 \%$ of the arboreal pollen in the Mindel-Riss deposit from Villaverde, Madrid (MenéndeZ Amor and Florschütz, 1959). Late-Glacial and Postglacial deposits from many parts of Spain indicate that it continued to be absent at this time (Picea is not found in the greater part of the Iberian Peninsula at the presentday). It was present, however, in the Holocene of the Pyrenees (BartLeY, 1962) where it still continues to grow. Although sporadic records of the genus are found before this, Picea does not appear to have been represented in large percentages prior to the Boreal or Atlantic in Mediterranean regions and the Atlantic or even Subboreal to Subatlantic further north. Although the genus appears to have maintained its hold in mountainous areas one finds in the majority of pollen analyses that it was fighting a losing battle with deciduous trees and particularly Fagus in the later part of most Postglacial sequences.

\section{Pinus (Fig. 5)}

This Northern Hemisphere genus is found in almost every region of Europe at the present-day. It appears to have been already differentiated in the Cretaceous for leaf-fascicles and cones resembling Pinus are found in rocks of this age, e.g., Gothan and Weyland (1964, p.359). Pinus is recognized chiefly on the basis of cones and the characteristic arrangement of needles in a fascicle (dwarf shoot). Single species of Pinus growing at the present-day may have from one to eight needles in one of these fascicles and although there is a certain amount of constancy within some groups of the genus one should not regard differences in number as an indication of the presence of a number of species. Specific rank is better based on characters of leaf width and structure, in the case of leaves. The actual number of species, from the European Tertiary, described on the basis of leaf and/or cone is in order of 140, which even allowing for many of these being synonymous is still a great number. Some 70 taxa are recorded from the Miocene and there seems to have been not only an expansion in the number of taxa but in actual numbers as well. On the other hand one may interpret the map as indicating a move to a lower altitude at this time, for this would increase the chances of preservation. The number of taxa described from the Pliocene (43) is not much fewer than that from the Miocene, although there seems to have been a genuine 


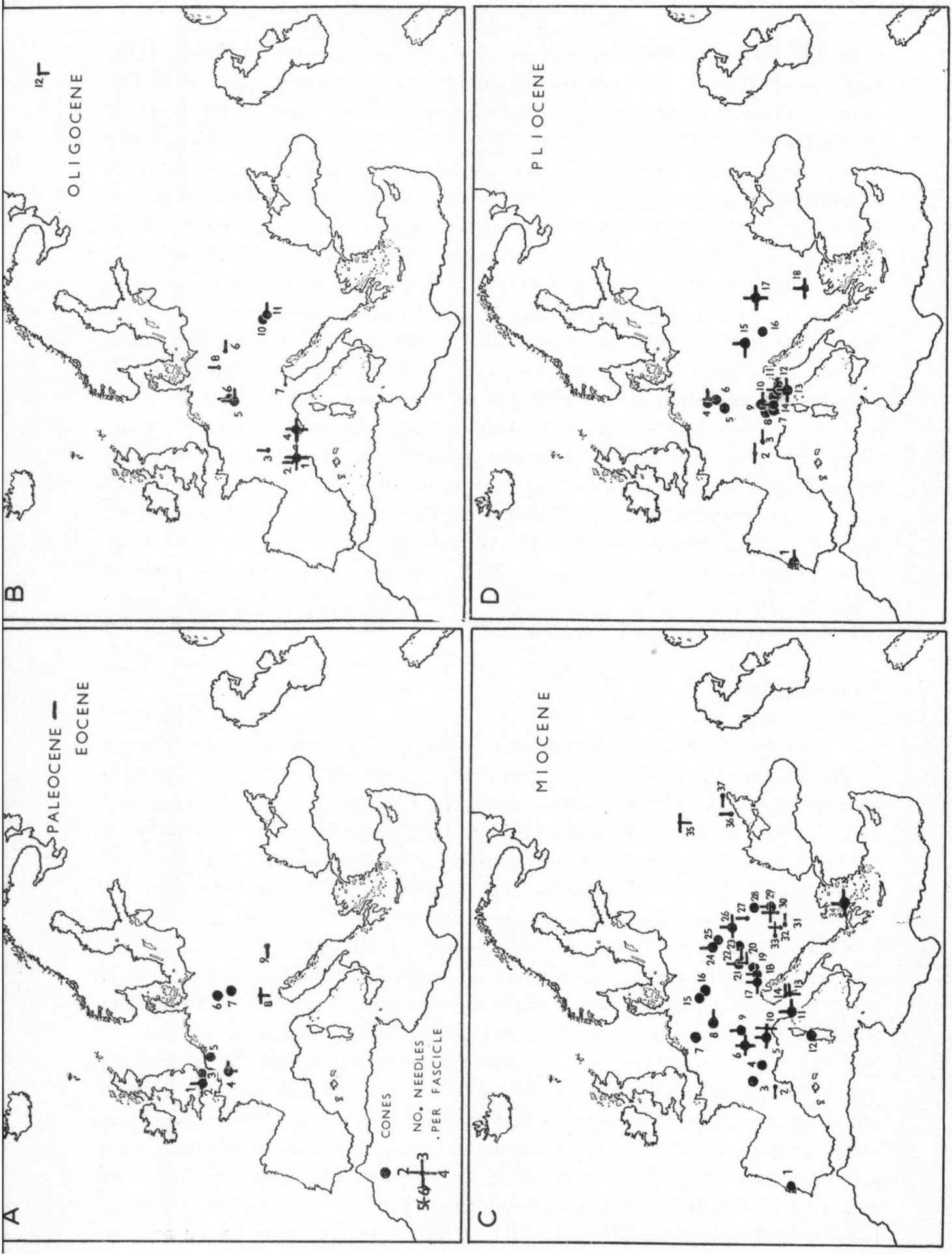

Palaeogeography, Palaeoclimatol., Palaeoecol., 3 (1967) 73-110 
Fig.5. The Tertiary distribution of Pinus, based on leaves and cones.

\section{A. Paleocene-Eocene}

$1=$ Chandler (1961b, pp.60-61-Paleocene); 2 = Chandler (1961a, pp.22-23, pl.9, fig.50Eocene); $3=$ Chandler (1961b, pp.56-58, pl.4, fig.1-7-Paleocene); $4=$ Watelet (1866, pp.112-113, pl.31, fig.5, pl.32, fig.16-17-Paleocene); 5 = Stockmans (1936, pp.24, 26, pl.3, fig.1-Eocene); 6 = BEYN (1940, p.406, pl.1, fig.5-Eocene); $7=$ KNOBLOCH (1962, p.104, pl.1, fig.7-Eocene); $8=$ Von Ettingshausen (1851b, p.35, pl.6, fig.23-33-Eocene); $9=$ Staub (1885, p.82, pl.1, fig.1-2-Eocene).

\section{B. Oligocene}

$1=$ De SAPORTA (1865, pp.59-80, pl.3, fig.1-4, 6-8, pl.4, fig.1-4, 9, 11, 12, pl.5, fig.1-3); $2=$ De SAPORTA (1865, p.77, pl.4, fig.11); 3 = Boulay (1899, p.83, pl.1, fig.5-Upper Oligocene or Lower Miocene); 4 = DE SAPORTA (1862, pp.212-216, pl.3, fig.2-6, 1868, pp.19-20, pl.1, fig.1, 1873, pp.15-22, pl.1, fig.17, pl.2, fig.4-6, 8-10, 1888, pp.46-56, pl.3, fig.9-11, 14-18, 20-22, pl.4, fig.1, 3-5, 7); 5 = Von ETtingshausen (1868, pp.826-827); ENGelhaRdT (1911, pp.322-325, pl.37, fig.35-36, pl.45); 6 = Von EtTingshausen (1868, pp.826-828); 7 = Principi (1926, p.24, pl.2, fig.2); 8 = FRIEDRICH (1883, p.220); ENGELHARDT (1888, p.10); 9 = ENGELHARDT (1870, p.33); $10=$ Von EtTingshausen (1853, pp.791-792); 11 = Von EtTingshausen (1853, p.792); Pálfalvy (1951, pp.63-64); 12 = DOROFEEV (1961, fig.7-8).

\section{Miocene}

$1=$ Teixeira (1945, p.209, citing O. Heer, 1881); 2 = Menendez AMOR (1955, p.45, pl.16, fig.1); $3=$ MarTY (1931, p.183); 4 = Boulay (1887, pp.237-238); 5 = SismondA (1865, pp.405-408, pl.4, fig.7, 11-13, pl.5, fig.4-6, pl.8, fig.3); $6=$ GAUdIN (1855, pp.357, 361, 429); HEER (1855, p.56, pl.21, fig.6); 7 = SCHLOEMER-JÄGER (1960, pp.222-237, pl.1, fig.7-12); $8=$ KRÄUSEL (1938, p.20, pl.3, fig.3-5); $9=$ Heer (1855, pp.56-57, pl.20, fig.4); $10=$ Peola (1899, p.46); $11=$ Berger (1957, pp.14-17, pl.1, fig.35-39, pl.2, fig.40-48); $12=$ Meschinelli and SQuinabol (1892, pp.122, 128-129); 13 = MASSALONGO and SCARABELli (1859, pp.158-159, 161, pl.5, fig.12-16, 34); Paolucci (1896, pp.1-4, pl.1, fig.1-2); 14 = Massalongo (1853, p.203, pl.3, fig.4); $15=$ Unger (1847, pl.19, fig.12); $16=$ MaI (1964, p.15, pl.1, fig.3); 17 = Von EtTINGShausen(1872, pp.167169, pl.1, fig.28-29, 31-34); 18 = VON ETTINGSHAUSEN (1890, pp.73-75, pl.1, fig.79, 87, 90-92); Berger (1955c, p.406); 19 = UNGer (1847, pl.20, fig.4, 7); 20 = Berger (1952a, p.96, 1953a, p.18); 21 = VONETTINGSHAUSEN (1851a, p.11, pl.1, fig.1 1); BERGer (1952b, pp.85-86, 1853b, p.143); Berger and ZABusch (1952, p.501, 1953, pp.231-232, fig.1); 22 = Berger (1951, p.274, fig.1); 23 = CZIFFERY-SZILÁGYI (1961, p.44, fig.5-8); 24 = SZAFER (1961, pp.19-20, pl.5, fig.4, 6-7, 9-11); $25=$ ZABLOCKI (1928, pp.182-187, pl.7, fig.1-7, pl.8, fig.1-5-Oligocene according to KIRCHHEIMER, 1950); $26=$ KoVATs (1856, pp.18-19, pl.1, fig.8-10); ANDREANSZKY (1959, p.51, pl.9, fig.11, pl.10, fig.1); $27=$ Givulescu (1951, p.111); GivulesCu and Nicorici (1960, p.182); $28=$ Givulescu (1952); 29 = Givulescu (1952); 30 = Barbu (1954, pp.25-26, pl.2, fig.3-11); $31=$ Pantić (1958, pl.2, fig.5b); 32 = Pantić (1958, pl.2, fig.7); 33 = Milaković (1956, pp.193-194, pl.1, fig.1); 34 = UnGer (1867, pp.43-45, pl.2, fig.1-11, 13-14, 16, pl.16, fig.12); $35=$ PalibiN (1901, p.470); 36 = TeslenKo (1959, fig.1); 37 = Kryshtofovich (1931, p.7, pl.1, fig.2-3).

\section{Pliocene}

$I=$ TeiXeira (1945, pl.1, fig.1-4, pl.2, fig.1-6); 2 = LaURent and MarTy (1905, p.95); De SAPORTA (1873, p.221); 3 = DePaPe (1922, pp.122-131, pl.2, fig.1-2); 4 = MülLER-STOLl (1938, pp.398-399); 5 = GeISSERT (1962, p.39); 6 = GEYLER and KINKELIN (1890, pp.11-15, 20, pl.1, fig.3-10, 16-17); KinKelin (1900, pp.127-128); ENGelhaRdT and KinKelin (1911, pp.201-210, 221, pl.24, fig.5-11); MäDLER (1939 p.35, pl.1, fig.36); KRÄUSEL (1940, p.448, pl.2 a-d); 7 = SQU1NABOL (1891, pp.19-20, 22, pl.15, fig.1, 4, 7); $8=$ GAUdIN and STROZZI (1858, pp.27-28, pl.2, fig.4); $9=$ SoRDELLI (1873, pp.371-374, fig.7-11, 1896, pp.111-115, pl.15, fig.12-14, pl.16, fig.15-16); 10 = Meschinell and SQuinabol (1892, p.126); 11 = CAvara (1886, pp.725-726, pl.1, fig.4); 12 = Meschinell and SQuinabol (1892, pp.124, 126); $13=$ Gaudin (1857, p.333); GAUDIN and STrozzi (1858, pp.26-29, pl.1, fig.1-3, pl.2, fig.1-3, 6, 1860, pp.33-34, pl.1); $14=$ SQuinabol (1891, p.21, pl.15, fig.3); $15=$ BERGER (1950, p.90, fig.3-8, 10, 1952b, pp.85-86, 1953, p.143, 1955a, pp.74-75, 1955b, pp.85-86, fig.14-15); 16 = CZIFFERY-SZILÁGYI (1964, pp.129130); 17 = Givulescu (1951, p.117, 1956a, pp.578-579, 1961, pp. 329-330, 1962, pp.134-135, fig.17-18, 27, 32-34, 208-213); $18=$ Stojanoff and Stefanoff (1929, pp.20-23, text fig.4, fig.5, pl.3, fig.4-6). 


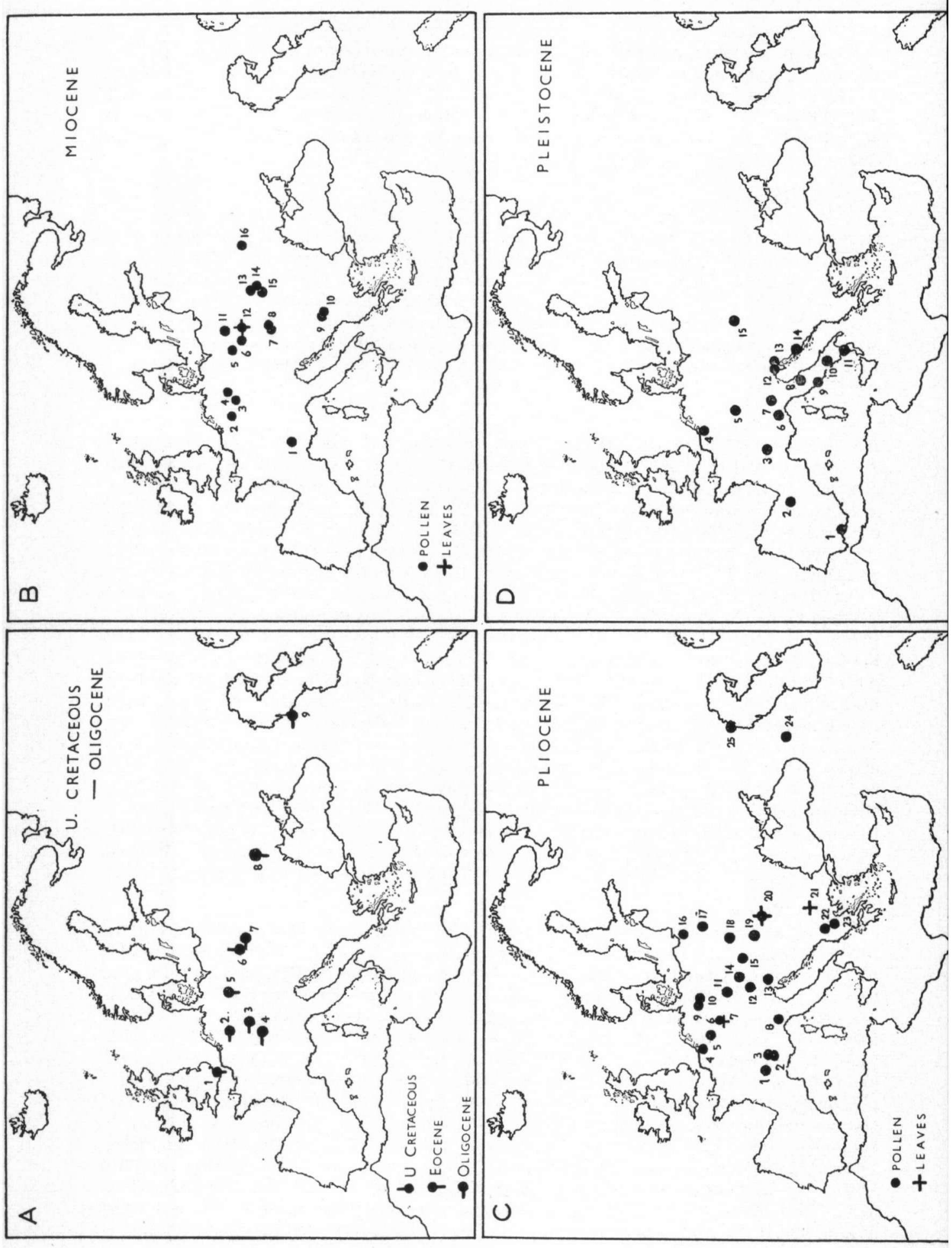

Palaeogeography, Palaeoclimatol., Palaeoecol., 3 (1967) 73-110 
reduction in numbers; indeed one would expect with the approach of the Ice Age that these conifers would tend to be found at lower altitudes. The lowering of the tree limit during glaciation may well have indirectly caused a certain amount of hybridization between species originally more or less isolated from one another on higher ground. Re-establishment on higher ground during the interglacials and the Postglacial would then tend to conserve any hybrids formed.

\section{Pseudolarix}

This genus has a present distribution in China, but since FLORSCHÜTz (1925)

Fig.6. The distribution of Tsuga in time and space, based on the occurrence of its pollen and leaves within sediments.

\section{A. Upper Cretaceous to Oligocene}

1 = MACKo (1963, pl.28, fig.7-8); $2=\operatorname{HeLAL}\left(1958\right.$, p.427); $3=\operatorname{KiRCHHEIMER}(1950) ; 4=\mathrm{K}_{\mathrm{IRCH}}$ HEIMER (1950); 5 = KIRCHHEIMER (1934, pp.175-176, fig.6); 6 = MACKo (1963, p.10, pl.1, fig.6-7); 7 = KIRCHHEIMER (1950-Miocene according to ZABLOCKI, 1928); $8=$ SHCHEKINA (1958); $9=$ Grossheim and Gladkova (1951, p.807, fig.1-Oligocene or Miocene).

\section{B. Miocene}

$I=$ FirTiON (1958, p.276); $2=$ MANTEN (1958, p.467); 3 = ThOMSON and ReIN (1949, p.109); 4 = KirChHeimer (1934, p.177, fig.8); 5 = DokTorowicz-HrebNicKa (1957b, p.170, pl.27, fig.5, pl.28, fig.14); $6=$ MAZANCOVÁ (1962, p.170, pl.6, fig.6); $7=$ SNOPKOVÁ (1961, p.220); $8=$ SNOPKOVÁ (1961, p.218); 9 = MiLAKoVIĆ (1961, p.46); $10=$ MiLAKOVIĆ (1960); $11=$ KremP (1950, p.62, pl.3, fig.10, 12-13); 12 = MACKo (1957, pp.33-34, pl. 7, 8, 9, fig.1-6); OszaST (1960, p.14, pl.4, fig.7-11); Szafer (1961, p.18, pl.5, fig.1-2); $13=$ ShChEKINA (1957, p.37); $14=$ ShCHEKINA (1957, p.37); 15 = ShCHEKINA (1958, pp.64-65); 16 = ShCHEKINA (1962, fig.47).

\section{Pliocene}

$I=$ Firtion (1946, pp.512-513); 2 = Pons (1964, p.609, photos 25-26); 3 = Ballesio and MeonVILAIN (1965, p.16); 4 = ZAGWIJN (1959, p.18, 1960, p.68); 5 = VAN DER BRELIE (1958, p.34); 6 = KirChHEIMER (1934, p.178); WOLfF (1934, p.70); RUDOLPH (1936, p.311); LESCHIK (1952, fig.4); LESCHIK (1956, pp.34-35, pl.16, fig.3-6); 7 = MÄDLER (1939, p.24, pl.1, fig.21-29); KRÄUSEL (1940, p.447, pl.1d); $8=$ LoNa $(1962$, p.90); $9=$ LeschiK $(1954$, pl.2, fig.3-7); $10=$ Thomson and Pflug (1953, pp.66-67, pl.4); $11=$ Rudolph (1936, p.267); .12 = MeYer (1956, p.123, pl.4); 13 = Weyland et al. (1958, p.77); 14 = PaCltová (1963, pl.7, fig.1-4); 15 = SNOPKOVA (1960, p.192, table 1); 16 = DoKTOROWICZ-HrebNicKa (1957a, p.156, pl.18); $17=$ DOKTOROWICZHrebnicKa (1957a, p.156, pl.18); 18 = Szafer (1954, pl.3, fig.6); $19=$ NaGY (1959, p.414); 20 = Givulescu (1956b, p.1234, fig.2, 1961, pp.329, 331, 1962, p.134, pl.25); $21=$ STOJANOFF and Stefanoff (1929, pp.15-16, pl.2, fig.7-9); 22 = PANTIC and Nicolić (1956, p.71); 23 = WeYland and Pflug (1957, p.100); Weyland et al. (1958, p.77; 1960, p.75, pl.10, fig.10); $24=$ Shatilova (1962, p.897); ChOCHIEva (1965, pl.1, fig.3); 25 = SUPRUNOVA and VRONSKII (1965, p.196).

\section{Pleistocene}

1 = MENENDEZ AMOR and Florschütz (1964, p.254); 2 = H. Remy (in: Woldstedt, 1958); $3=$ DuRAND and ReY (1963, p.2692); 4 = ZAGWIJN (1959, p.18; 1960, p.68); VANHOORNE (1963, pp.89-90); Greguss and VanHOORNE (1964, pl.1, fig.2-3); $5=$ Leroi-Gourhan (1961); $6=$ Follieri (1957, p.92, pl.3, fig.t-3); 7 = LoNa (1950, pl.1, fig.4-9); 8 = PAGANELli (1960, p.603); LONA and RiCCIARDI (1961b, pl.1, fig.7); $9=$ BlanC (1955); 10 = RICCIARDI (1963, p.868); $11=$ LoNA and RICCIARDI (1961a); $12=\mathrm{A}$. Sercelj (unpublished); $13=$ SerCeL (1961); $14=$ SerCeL $(1965$, pl.1); 15 = SzAFER (1954, fig.9). 
first described it as occurring in the Pliocene deposits of the Dutch-German border it has been recorded from a number of other localities in Europe, and also in Asia (e.g., KryShTofovich, 1956; DorofeEv, 1961). Various attempts have been made to find some characters on which to separate the pollen from that of Pinus but so far the investigations have not been carried far enough. The leaves are arranged in whorls but these appear to be shed as separate entities and as such are none too easy to distinguish from other similar forms. The imbricate cone-scales are shed in a similar manner to the leaves and present difficulties, since these scales resemble those of a number of other genera. The seed does, however, appear to differ from the seeds of other members of the Pinaceae in having a wing which is gradually tapered into a sharp point. In Europe the genus appears to have been present only in the Upper Tertiary.

\section{Tsuga}

This genus has a present distribution in North America and the Far East; fossil remains (pollen grains and leaves) have been found in the Tertiary of both these regions. The cone, although unusually small for the Pinaceae, could be confused with immature cones of a number of other genera. The seeds, although small, are typical of those found within the Pinaceae. As far as recognizing remains of this genus go the small petiolate leaves of the genus and the frilled pollen grains are most distinctive. On the basis of these remains it is possible to say that the genus was present in Europe as early as the Upper Cretaceous and remained there well into the Pleistocene (Fig.6).

The pollen grains and leaves are frequently found in a number of forms in the Tertiary and Lower Pleistocene. Oszast (1960, p.14) described three Miocene species (plus one referred to Tsuga pattoniana, a possible cross between Tsuga and Picea) on the differences found within the pollen. One of these was referred to the eastern species Tsuga sieboldii but it is usually considered that the affinities of both leaves and pollen grains were with the present-day North American species (see SzAFER, 1949). Although its geographical range does not appear to have been obviously restricted at the beginning of the Pleistocene it probably no longer occurred in the major part of Europe after the Mindel Glaciation except, for example, in some parts of southern Italy where it is recorded in the Mindel-Würm Interglacial and in northern Yugoslavia where it is found regularly in deposits belonging to the Riss-Wurm Interglacial (A. Sercelj, unpublished, 1966). Why it disappeared from Europe at all is a matter for speculation for it is a tree resistant to frost and tolerant of a heavy weight of snow. 


\section{PODOCARPACEAE}

\section{Dacrydium}

Pollen of this genus has been described (but not illustrated) from the Miocene of the northern part of the Black Sea depression (Korallova, 1962), but so far no definite records of the genus have been reported from Europe. ZaKLINSKaYA (1953, p.65, pl.1, fig.12a, b) has found pollen grains with very small bladders about a quarter the size of the corpus and closely resembling that of Dacrydium franklinii, a Tasmanian species, in Tertiary deposits from the Pasekov mine in the Voronezh district of the U.S.S.R. Similar pollen has been found in the Tertiary of Kerguelen Island, Australia, Tasmania, and New Zealand and it may also have been present in South America at that time (CouPER, 1960, pp.494-495).

\section{Microcachrys}

This is another Tasmanian member of the Podocarpaceae. When uncompressed its vegetative shoots are fairly easily recognized, having a square crosssection and differing in other respects from the other genera with this characteristic. Its cone too is fairly characteristic but it is the pollen, small with three bladders 18-21 $\mu$ in long dimension, that is so distinctive. Pollen of this type has been found in the Lower Miocene of Gliwice in Poland (MACKo, 1957, p.44, pl.35, e.g., fig.12, 16). This brings up the whole problem of its past distribution. Besides this European record it only appears to have been found in the Late Mesozoic and Tertiary of southern Australia, Tasmania and New Zealand and in the Tertiary of Kerguelen Island (COUPER, 1960, pp.496-497), a far cry from its occurrence in the Northern Hemisphere.

\section{Phyllocladus}

This largely Southern Hemisphere genus has been reported from the Lower Tertiary sediments near Kiev in European Russia (KRASNOVA, 1910, p.217). The specimen on which Phyllocladus charkoviensis was based is a roughly triangular leaf with fine radiating, sometimes dicotomising, ribs. Although it might be a member of the genus Phyllocladus this is not the only possibility open. So far fossil remains of Phyllocladus have only been found in Australia and New Zealand (CouPER, 1960; FLORIN, 1963) with certainty, although pollen resembling Phyllocardus is found in the Tertiary of North America and the Far East.

\section{Podocarpus}

This is a largely Southern Hemisphere genus, but one which reaches, for example, latitude $38^{\circ} \mathrm{N}$ in Japan. The fleshy "fruit" with its enclosed seed is not 
distinctive, being easily confused with certain angiospermous fruits. Leaves too, unless their cuticles are investigated, are indistinctive, which accounts for records of the genus being later transferred to Bambusa (e.g., MARTY, 1931), various other conifers and to dicotyledonous plants. The pollen grains of Podocarpus, sometimes coarsely sculptured or with a fine, poorly-developed, reticulum in the often huge bladders (in comparison with the size of the corpus) differentiate it from all but a few species of Dacrydium. Although FLORIN (1963, p.198) did not believe the genus was ever present to the north of the Tethys, there are numerous reports based on palynological investigation which, if they are all to be believed, would give the genus a range in Europe from Triassic to Pleistocene. The author has restricted himself to an examination of the figured records. Such records appear to indicate that as far as the Tertiary goes Podocarpus pollen may be found in Eocene rocks (MACKo, 1963, pl.28, fig.9), in the Oligocene (KIRCHHeIMER, 1950, fig.1 a-c; ThIERGart, 1958, p.449, pl.1, fig.15), the Miocene (Potonit et al., 1950, p.49, pl.C, fig.6; Macko, 1957, e.g., pl.9, fig.13-15, 1959, pl.2, fig.9-12; Oszast, 1960, p.10, pl.2, fig.10, pl.3, fig.1), Pliocene (Pflug, 1959, p.152, pl.14, fig.6) and Pleistocene (GREGUSS and VANHOORNE, 1964, pl.1, fig.1). Unfortunately none of the authors, with the exception of Oszast, gives anything more than a taxonomic treatment, so that one cannot be sure whether at least some of these records are the result of redeposition from older beds. What one can be sure of from these records is that Podocarpus did, contrary to Florin's expressed opinion, exist in Europe at one time, and there are similar records indicating that it occurred in Asia as well (ABuziaroVA, 1958, p.150, pl.1, fig.6; ZAKLINSKAYA, 1953, e.g., pl.1, fig.2-4, 10). The diagrams in Oszast's work shows that Podocarpus pollen is found in an almost continuous curve, with a maximum representation of $10 \%$ of the total pollen. This is good evidence for saying that the genus must have been present in the environs of Stare Gliwice in Poland during the Tortonian (Miocene). The general form of most of the Podocarpus pollen grains found is that with two laterally placed bladders. One of those recorded from the Lower Tertiary of the Turgay Depression just north of the Aral Sea in Kazachstan is, however, of the type with three bladders. Such pollen is characteristic of Podocarpus section Dacrycarpus. Freak pollen with three bladders does occur in a number of other genera, but this does not appear to have been a freak for it is found to compose $2.5 \%$ of the total pollen present in the deposit. Podocarpus section Dacrycarpus is to be found at the present-day in Malaya, Java, Borneo, New Guinea, New Caledonia, and New Zealand, and pollen of it has been described from Mesozoic and Tertiary rocks of New Zealand and Australia (Couper, 1960, p.495). Another record, but one which may simply be a freak Abies was described and figured from the Hungarian Miocene by NaGY (1962) as Dacrycarpites hungaricus.

The author has already mentioned how cuticles may help to identify Podocarpus from leaf remains. One such case from the Pliocene of Frankfurt-am-Main (Germany) has been described by MäDLER (1939) as Podocarpus kinkeli. But al- 
though he investigated the cuticle of this leaf (MÄDLER, 1939, pl.2, fig.5) the fragment illustrated does not appear to be sufficient to distinguish it from genera such as Cephalotaxus and Austrotaxus, although the shape of the leaf does resemble Podocarpus rather than those of the afore-mentioned genera. On the other hand, the leaf he described as Cephalotaxus pliocaenica (MäDleR, 1939, pl.1, fig.2, 3) should, in my opinion, be referred to Podocarpus on the nature of its stomata and adjacent cells. This determination must, however, be considered tentative.

\section{SCIADOPITYACEAE}

\section{Sciadopitys}

This Japanese genus can be recognized on the basis of a number of characteristics. The nature of the structurally double leaf, its cuticle and the arrangement of the leaves on the shoot are very distinctive. The large cone-scales distinguish it from those of Sequoia and the pollen of the genus with its hemispherical projections are both diagnostic; only the seed cannot claim to be distinctive. There are preTertiary records of the genus based on pollen and, on the basis of leaves and their cuticles FLORIN (1922) showed that this genus or at least near relatives of it has been in Europe since the Rhaetic. The genus appears to have been widespread in the Older Tertiary, being found not only in Eurasia but also in America. In the Younger Tertiary Sciadopitys disappeared from America and its distribution within Eurasia became divided into two areas, respectively Europe and the Far East. In Europe the genus persisted into the Early Pleistocene.

\section{TAXACEAE}

\section{Amentotaxus}

This is a genus found at the present-day in Formosa, China and Vietnam. Its pollen is not distinctive, being round, non-aperturate and only finely ornamented and it is to the leaves that one turns for evidence of its past history. The leaves, which are large, are arranged on the shoot in two opposite ranks. The cuticle is unique amongst living conifers in having stomatal accessory cells arranged in a markedly radiate fashion. Leaves with such a cuticle have been described from the Miocene browncoal of Salzhausen in Germany as Amentotaxus florini (KRÄUSEL, 1935). Since than such leaves have been found in another Miocene locality, namely that of Kreuzau in Germany, and are under investigation by the present author. Much of the material of the living species which has been collected has been found to be sterile and $\mathrm{LI}$ (1952) in his revision made much use of the leaf characters in his 
classification of the genus. A comparison of the leaf morphology of the fossil species with that of the living species reveals that a most striking similarity exists between the fossil species Amentotaxus florini and the living Amentotaxus cathayensis from western China.

Taxus

This largely Northern Hemisphere genus is at present widespread in western Europe, where it appears to have been present in the past as well. Although the wild taxa within this genus are recognized without any difficulty this genus causes some trouble when it comes to identifying the individual organs. The fleshy aril is unlikely to enter the fossil record and the seeds might well be confused with those of certain angiosperms. The pollen is wingless and inaperturate and could easily be confused with similar pollen occurring in the Cupressaceae. Taxus can, however, be distinguished from other genera on the basis of a combination of leafshape, leaf anatomy and the cuticular characters. Investigations making use of cuticular characters have turned up two records of the genus in the European Tertiary: one from Kokoschütz in Schlesien (KRÄUSEL, 1918, pp.345-349, pl.17, e.g., fig.6, 7, pl.18, fig.1, 2) attributed to transitional beds between the Oligocene and Miocene and another from the Pliocene of Willershausen in Germany (STRAus, 1952, p.20, pl.4, fig.6, 7, pl.7, fig.28-30). In an attempt to recognize further occurrences of the genus simply on the basis of their leaves and their arrangement on the shoots the present author undertook a special study of the living species of the genera Taxodium, Sequoia, Glyptostrobus, Taxus, and a number of species of Podocarpus ( $P$. andinus, $P$. spicatus and $P$. ferrugineus). Of the characters liable to show up in fossils he chose to measure the length and breadth of the leaves in relation to their position on the shoot, the angle at which the leaves arise from axis of the shoot, the width of the axis of the shoot at each node and the number of leaves per centimetre of the shoot. Living species of Taxodium and Glyptostrobus appeared to differ from the other genera in the narrow apex to the shoot-axis $(0.2-0.3 \mathrm{~mm}$ as opposed to $0.5-0.9 \mathrm{~mm}$ in the other genera) and to have narrower leaves at the apex (0.3-0.6 $\mathrm{mm}$ as opposed to the other genera in which the width appeared to remain constantly at $\mathbf{0 . 7} \mathrm{mm}$ or more). Unfortunately it was found impossible to find a water-tight separation between Taxus and Podocarpus or even Sequoia and until more work is done with cuticles one has to look upon the majority of the records of Taxus with suspicion.

\section{Torreya}

This genus now occurs in a number of patches in eastern and western North America and in a more extensive region in Japan and neighbouring China and Burma. The fleshy "fruit" with its enclosed seed resembling that of a number of 
angiospermous genera is not the best evidence on which to base the fossil history of the genus. The pollen too is very indistinctive in being round, without any apertures and ornamented with only small spicules. The leaves are the best clue as these bear a long spine at their apex. The central ridge of the leaves is wide, about a third of the total width. Such leaves have been found in the Pliocene of Germany and the south of France, determinations which have been confirmed in the case of the German specimens by cuticular analysis (MÄDLER, 1939, pp.13-14, pl.2, fig.1-3; STRAus, 1952, pp.20-21, pl.6, fig.1-22, 27-31). Earlier records, for example, that of SCHULze (1887) from the Upper Cretaceous have not yet been confirmed.

\section{TAXODIACEAE}

\section{Athrotaxis}

This genus is the only Southern Hemisphere member of the Taxodiaceae, being found in Tasmania at the present-day. Fossils have been found in South America, Australia, and New Zealand (see FloriN, 1963) and the genus is also reported from the Northern Hemisphere (e.g., ZALEwSKA, 1959; DOROFEev and Svechnikova, 1963). Zalewska reported it from the Lower Miocene of Turów, in Bohemia, on the basis of scaly shoots bearing cones, with the typical broad escutcheon and spiny process. These specimens appear to be Athrotaxis or closely allied to it. DoROFEEv and SvechNIKOVA (1963) have reported the same genus from the Lower Tertiary sediments in the Kaliningrad region. The determination was based on poorly preserved and consequently indeterminate cones and on fragments of vegetative shoots, which were examined for cuticles (DOROFEEV and SVECHNIKova, pl.10, fig.1-5). In their description of the cuticle, Dorofeev and Svechnikova make much of the papillae present in the fossil, but such papillae are not only found in Athrotaxis but in other genera having similar scale-like leaves as well, e.g., Juniperus phoenicea L., J. sabina L., Podocarpus cupressinus R.BR., and Widdringtonia whytei RENDLE. The other features of the cuticle remain an insufficient basis on which to make this generic assignment.

\section{Cryptomeria}

At the present-day this genus has a distribution in China and Japan. In the European Tertiary there are vegetative shoots assigned to Cryptomeria sternbergii but their actual affinity is less certain. These vegetative shoots have not only been classified under Cryptomeria but under Araucaria and Sequoia as well. In one case, however, such vegetative shoots have been found bearing cones (GARDNER, 1886, pl.21, fig.1). This appears to be an authentic record of Cryptomeria in the Tertiary of Europe. Radiometric dating of the overlying basalts (MILLER and HARLAND, 
1963) indicates that the age of the deposit in County Antrim (Northern Ireland), in which this fossil was found, is Paleocene, not Eocene or Miocene as various authors have thought. Cryptomeria has been reported from Upper Miocene sediments east of the Black Sea (Svechnikova, 1953, pl.1, fig.1-4). The cuticle of this specimen was examined and, although from all the characters the specimen does appear to be a Cryptomeria, an affinity with Taxodium ascendens is not to beentirely ruled out.

\section{Cunninghamia}

A genus found in China and on the Island of Taiwan at the present-day it would appear that Cunninghamia had a much larger distribution in the past. The pollen of this genus is wingless and non-aperturate and is liable to be confused with a number of other genera with similar pollen. The same can be said of the cone and it is to the leaves with their finely serrated margin that one must turn to for information bearing on its past distribution. Leaves attributed to Cunninghamia have been described from the Cretaceous from many parts of the world, including that of Europe (e.g., HeER, 1869, 1871), but the illustrations do not show the typical serrations which distinguish this genus from Araucaria. The first valid record of the genus appears to be that from the Lower Tertiary of Mull, an island off the west coast of Scotland (JoHNSON, 1936), although the record still awaits the confirmation of cuticular analysis. Leaves attributed to Cunninghamia and confirmed by cuticular analysis have been found in the Lower Tertiary of the Kaliningrad Peninsula, beside the Baltic Sea (Svechnikova and Bydantsev, 1959). In the Miocene twig and leaf remains have been found at Stare Gliwice in Poland (SzAFER, 1958, 1961) and at Sagor near the border of Austria and Yugoslavia (VON EtTINGSHAusen, 1872, p.867). After the Miocene it appears to have been absent from Europe.

\section{Metasequoia}

This Chinese genus with its small opposite leaves can be distinguished from other genera with a similar leaf arrangement by the width of the axis of the dwarf shoot, which is less than $0.7 \mathrm{~mm}$ in diameter. Its laterally elongated cone-scales too are sufficient to distinguish it from other members of the Taxodiaceae. Neither pollen nor seedscan be used successfully. Fossil remains attributable to Metasequoia have been found in the Paleocene of Mull, an island off the mainland of Scotland (M. E. J. Chandler, personal communication, 1963), in the Paleocene-Eocene of Spitzbergen (SCHLOEMER-JÄGER, 1958) and in the Lower Tertiary of Mikines in the Faeroe Islands (RASMUSSEN and KoCH, 1963). Metasequoia has also been reported from the Lower Miocene of Bohemia (ZALEWSKA, 1959). Zalewska described a new species, Metasequoia europaea on the basis of seeds, vegetative shoots and cones. As Zalewska pointed out it is either very difficult or altogether impossible to dis- 
tinguish the seed of Metasequoia from that of Sequoia on the basis of morphological characters. Tissue preparations made from the wing of the seed (pl.13) do resemble those of Metasequoia rather than those of Sequoia but no attempt was made to compare the seed with other members of the Taxodiaceae. The determination can, therefore, only be considered tentative. It is not certain whether the leafy shoot attributed by Zalewska to Metasequoia had the leaves arranged in two opposite ranks. In any case the diameter of the axis of the shoot, 1-2 $\mathrm{mm}$, appears to be too large to be assigned to Metasequoia which has an axis of only $0.4-0.7 \mathrm{~mm}$ in diameter when it is leaf-bearing. The poorly-preserved cones have cone-scales similar in shape to those of Metasequoia, but they are rather small and unless they belonged to an immature cone their assignation to Metasequoia is questionable. It is not altogether surprising that DorofeEv and Svechnikova (1963) considered Metasequoia europaea a synonym for Athrotaxis taxiformis. SCHÖNFELD (1956) described as Taxodioxylon metasequoianum woods resembling that of Metasequoia from the Miocene of Düren in Germany but the wood of Metasequoia is not distinct enough to warrant an assignation to Metasequoia (see also ZALEwSKA, 1959, p.119). A detailed investigation of the cones from the same quarry did not reveal any cones attributable to Metasequoia (SCHLOEMER-JÄGER, 1959, 1960). For the present it appears that Metasequoia was only to be found in Europe during the Early Tertiary and was restricted to the more northerly latitudes.

\section{Sequoia}

An American genus and somewhat difficult to recognize in the fossil state. The pollen is hard to distinguish from that of Cryptomeria, the seeds are of a type common in the Taxodiaceae and the shoots unless investigated for cuticles may be confused with Taxus and some species of Podocarpus. The cuticle, if used in conjunction with the other features of the leaf, will identify the genus (the cuticle is seen to be tripartite) and the cone can also be used. This genus was almost certainly present in Europe from the Oligocene into the Pliocene, and may have also been present at earlier times.

\section{Taiwania}

This genus has a present disjunct distribution in China and Taiwan. Besides the Pliocene records of the genus from Japan macrofossils attributed to Taiwania have been found in the Paleocene-Eocene of Spitzbergen (SCHLOEMER-JÄGER, 1958) and in the Eocene of the area just north of the Black Sea (SvechNikova, 1963). In the latter case cuticles were prepared from the vegetative shoots but the cuticle is insufficient to allow one to assign the fossil to Taiwania. The record from Spitzbergen consists of vegetative shoots bearing cones agreeing in all respects with those of Taiwania. 


\section{Taxodium}

This genus occurs in the southern and eastern U.S.A. and Mexico at the present-day. In the Tertiary it appears to have occurred all over the Northern Hemisphere. Vegetative shoots with alternating leaves, when these are short, narrow and projecting distally at an angle in the order of $40^{\circ}$ should establish the presence of the genus, but it ought to be added that the shoots of Taxodium species are not always of this type. The cone of Taxodium is distinct from those of other genera and on the basis of such cones and the distinctive form of the vegetative shoots one can establish the presence of the genus in the Lower as well as the Upper Tertiary. Pollen records are not always to be trusted for the small pear-shaped grains are of a type found within a number of other genera. The seed is difficult to identify since this is wingless. Throughout the Tertiary Taxodium appears to have been widespread in Europe and did not disappear from the area until the end of the Pliocene.

\section{CONCLUSIONS}

The present paper is an attempt to outline some of the major features of conifer phytogeography within the European Cenozoic. One of the things which is apparent in such a geographical study is that one is largely confined to considering diminution in area rather than the converse. There seem to be two factors involved. The first one concerns the origins of the taxa concerned. Such origins are apparently difficult to pin-point in space and time, because initially at least a taxon is barely differentiated and by the time it has become a distinctive entity it has already had a chance to become widely distributed. The second reason is that one hesitates to make any conclusions on the basis of what can only be considered uneven and incomplete sampling. Even in those deposits which appear to have been thoroughly worked on in the past, new finds, often resulting from the development of new techniques, are continuing to be made. Consequently the apparent absence of a particular taxon is not always a very sound basis on which to say that the particular taxon was not at one time present in the area. This is particularly true in the case of macrofossils and it is possible that the solutions to a number of problems of distribution lie more in the field of micropalaeontology. One of the disadvantages of working with pollen, however, is that the actual distributional boundaries will tend to be unclear. This is a direct consequence of the ability of these microfossils to have been transported over long distances. Preferably one should use evidence from reliably determined macro- and micro-fossils in conjunction. It is necessary to stress that these fossils should be reliably determined if the resulting geographical distributions and the conclusions based on them are to have any validity.

One of the things always to be borne in mind is that almost invariably one is 
dealing with isolated organs and one has, consequently, to try to avoid taking determinations farther than the fossil warrants. Sometimes it is only possible to describe the fossil and leave its systematic affinity open to question. Authors, of which the present author is no exception, are naturally loathe to have too many "incertae sedes" as it seems to reflect a certain inability on their part. It may well be that some of the distributional patterns presented here have to be somewhat trimmed or even reconsidered.

\section{ACKNOWLEDGEMENTS}

The present paper was read in part at the joint symposium of the Systematics and Palaeontological Associations entitled "Tethys, an ancestral Mediterranean" in Leicester, England (September 21-23, 1966). I am truly grateful to Dr. W. G. Chaloner for reading through the paper and preventing me from falling into a number of serious errors. My thanks are also due to Professor Dr. F. P. Jonker who suggested a number of improvements to the manuscript.

\section{REFERENCES}

Abuziarova, R. Y., 1955. Rezul'taty sporovo-pyl'tsevykh issledovaniy oligotsenovykh otlozheniy Shintuzsaya (Turgay). Akad. Nauk Kaz. S.S.R., Inst. Zool. Materialy Istor. Fauny Flory Kazakhsk., 1: 126-137.

Abuziarova, R. Y., 1958. Sporovo-pyl'tsevyye kompleksy indrikoteriyevoy svity Akinoly (Turgayskiy progib). Akad. Nauk. Kaz. S.S.R., Inst. Zool. Materialy Istor. Fauny Flory Kazakhsk., 2: 149-156.

ANDreanszKy, G., 1959. Die Flora der Sarmatischen Stufe in Ungarn. Akadémiai Kiado, Budapest, $360 \mathrm{pp}$.

AyTuG, B., 1961. Etude des pollens du genre cèdre (Cedrus LINK). Pollen Spores, 3(1): 47-54. Ballesio, R. et MeON-VILAIN, H., 1965. Quelques observations sur le Pliocène de la région de Roussillon (Isère). Doc. Lab. Géol. Fac. Sci. Lyon, 9: 3-17.

Barbu, Z. I., 1954. Flora fosilă din tertiarul Olteniei. Anuar. Com. Geol., Rep. Populara Romina, 27: 5-76.

Bartley, D. D., 1962. Pollen analysis of a small peat deposit at Baños de Tredos, near Viella in the Central Pyrenees. Pollen Spores, 4(1): 105-110.

Berger, W., 1950. Die Pflanzenreste aus den unterpliozänen Congerienschichten von BrunnVösendorf bei Wien. Sitz. Ber. Osterr. Akad. Wiss., Math. Naturw. Kl., Abt. 1, 159(1/5): 87-99.

Berger, W., 1951. Pflanzenreste aus dem tortonisch Tegel von Theben-Neudorf bei Pressburg. Sitz. Ber. Osterr. Akad. Wiss., Math. Naturw. Kl., Abt. 1, 160(3/4): 273-278.

BERger, W., 1952a. Pflanzenreste aus dem miozänen Ton von Wiengraben bei Drassmarkt (Mittelburgenland). Sitz. Ber. Osterr. Akad. Wiss., Math. Naturw. Kl., Abt. 1, 161(2/3): 93-101.

Berger, W, 1952b. Die altpliozäne Flora der Congerien-Schichten von Brunn-Vösendorf bei Wien. Palaeontographica, B, 92: 79-121.

Berger, W., 1953a. Pflanzenreste aus dem miozänen Ton von Wiengraben bei Drassmarkt (Mittelburgenland), II. Sitz. Ber. Osterr. Akad. Wiss., Math. Naturw. Kl., Abt. 1, 162 (1/2): 17-24. 
Berger, W., 1953b. Pflanzenreste aus den obermiozänen Ablagerungen von Wien-Hernals. Ann. Naturhist. Museums. Wien, 59: 141-154.

Berger, W., 1955a. Nachtrag zur altpliozänen Flora der Congerienschichten von Brunn-Vösendorf bei Wien. Palaeontographica, B, 97: 74-80.

Berger, W., 1955b. Die altpliozäne Flora des Laaerberges in Wien. Palaeontographica, B, 97: 81-113.

Berger, W., 1955c. Jungtertiäre Pflanzenreste aus dem unteren Lavanttal in Ostkärnten. Neues Jahrb. Geol. Paläontol., Abhandl., 100(3): 402-430.

BERGER, W., 1957. Untersuchungen an der obermiozänen (sarmatischen) Flora von Gabbro (Monti Livornesi) in der Toskana. Paleontol. Ital., 21: 1-96.

Berger, W. und Zabusch, F., 1952. Die Pflanzenreste aus der obermiozänen Ablagerungen der Türkenschanze in Wien (Vorläufiger Bericht). Sitz. Ber. Österr. Akad. Wiss., Math. Naturw. Kl., Abt. 1, 161 (7): 499-507.

Berger, W. und ZABUSCH, F., 1953. Die obermiozäne (sarmatische) Flora der Türkenschanze in Wien. Neues Jahrb. Geol. Paläontol., Abhandl., 98: 226-276.

BeuCHER, F., 1963. Flores quaternaires au Sahara nord-occidental d'après l'analyse pollinique de sédiments prélevés à Hassi-Zguilma (Saoura). Compt. Rend., 256(10): 2205-2208.

BEYN, W., 1940. Über die Einschaltung geformter Pflanzenreste in das Braunkohlenprofil des mittleren Geiseltales. Nova Acta Leopoldina, 8: 377-438.

Blanc, A. C., 1955. Richerche sul Quaternario Laziale, III. Quarternario, 2: 187-200.

Bolkhovitina, N. A., 1956. Atlas spor i pylec iz iurskich i nijnemielovyh otlojenii vilniuskoi wyadiny. Tr. Inst. Geol., Akad. Nauk S.S.S.R., Geol. Ser., 2: 1-132.

BORG, J., 1927. Descriptive Flora of the Maltese Islands Including the Ferns and Flowering Plants. Malta, $846 \mathrm{pp}$.

Boulay, N., 1887. Notice sur la flore tertiaire des environs de Privas (Ardèche). Soc. Botan. France, 34: 227-239, 255-279.

Boulay, N., 1899. Flore fossile de Gergovie (Puy-de-Dôme). Ann. Soc. Sci. Bruxelles, 23: 55-132.

BrattSeva, G. M., 1962. Recent data on the flora of the bordering zone between the Cretaceous and the Paleogene in the region of the Zeisk-Burein depression. Dokl. Akad. Nauk. S.S.S.R., 143(1): 167-170 (in Russian).

Cavara, F., 1886. Sulla flora fossile di Mongardino. Mem. R. Acad. Sci. Inst. Bologna, 7-8.

Chandere, M. E. J., 1961a. Post-Ypresian plant remains from the Isle of Wight and the Selsey Peninsula, Sussex. Bull. Brit. Museum, Geol., 5(2): 13-41.

Chandler, M. E. J., 1961b. The Lower Tertiary floras of southern England, 1. Paleocene floras; London Clay flora (supplement). Monographs Brit. Museum, Geol., 354 pp.

Chochieva, K. I., 1965. Flora i Rastitel'nost' Chaudinskogo Gorizonta Gurii. Tr. Inst. Paleobiol., Akad. Nauk. Gruz. S.S.R., 1965: 1-149.

Chun, W.-Y. and Kuang, K.-Z., 1958. Genus novum Pinacearum ex Sina australi et occidentali. Botan. Zh., 43(4): 461-470.

COUPER, R. A., 1960. Scuthern hemisphere Mesozoic and Tertiary Podocarpaceae and Fagaceae and their palaeogeographic significance. Proc. Roy. Soc. London, Ser. B, 152(949): 491-500.

Cziffery-SzilágY, G., 1961. Beiträge zur Kenntnis der Tertiärflora Ungarns. Ann. Hist. Nat. Musei Natl. Hung., 53: 35-48.

CzIfFery-SziláGYi, G., 1964. Unterpannonischer Koniferenzapfen aus Szilágy (Mecsekgebirge). Ann. Hist. Nat. Musei Natl. Hung., 56: 129-130.

Davis, P. H., 1965. Flora of Turkey. Edinburgh Univ. Press, Edinburgh, 1: 567 pp.

DEPAPE, G., 1922. Recherches sur la flore pliocène de la vallée du Rhône. Flores de Saint-Marcel d’Ardèche et des environs de Théziers (Gard). Ann. Sci. Nat., Botan. Sér. 10, 4: 73-266.

De Saporta, G., 1862. Études sur la végétation du sud-est de la France à l'époque Tertiaire. Lignites inférieurs. Ann. Sci. Nat. Botan., Sér. 4, 17: 191-311.

De Saporta, G., 1863. Etudes sur la végétation du sud-est de la France à l'époque Tertiaire. Gargas, Sault, Gignac près Apt. (Vaucluse), Castellane. Ann. Sci. Nat. Botan., Sér. 4, 19: 5-124.

De Saporta, G., 1865. Etudes sur la végétation du sud-est de la France à l'époque Tertiaire. Armissan près Narbonne (Aude). Ann. Sci. Nat. Botan., Sér. 5, 4: 5-264. 
De Saporta, G., 1868. Etudes sur la végétation du sud-est de la France à l'époque Tertiaire. Argiles du bassin de Marseille. Ann. Sci. Nat. Botan., Sér. 5, 9: 5-62.

De SAPorta, G., 1873. Etudes sur la végétation du sud-est de la France à l'époque Tertiaire. Supplément, Aix, Révision. Ann. Sci. Nat. Botan., Sér. 5, 17: 5-44.

De SaPorta, G., 1888. Études sur la végétation du sud-est de la France a l'époque Tertiaire. Dernières adjonctions, Aix. Ann. Sci. Nat. Botan., Sér. 7, 7: 1-104.

De SAPORTA, G. et Marion, A. F., 1878. Essai sur l'état de la végétation à l'époque des marnes heersiennes de Gelinden. Acad. Roy. Sci. Lett. Beaux-arts Belg., 37: 1-112.

Diniz, F., 1965. Note préliminaire sur la flore pollinique du gisement d'Espadanol a Rio Maior (Portugal). Pollen Spores, 7(2): 373-380.

Doktorowicz-Hrebnicka, J., 1957a. Wzorcowe spektra Pylkowe Plioceńskich Osadów Weglonośnych. Inst. Geol. Prace, 15: 87-136.

DoKToRowicZ-HrebnicKA, J., 1957b. Z badan̆ mikrofloristycznych wegł bruatnego w Miroslawicach na Dolnom Słasku. Inst. Geol. Prace, 15: 167-186.

Dorofeev, P. I., 1961. Recent data from the Tertiary flora from the region of the Antropovo village on the Tavda river. Dokl. Akad. Nauk S.S.S.R., 133(1): 211-213 (in Russian).

Dorofeev, P. I. i Svechnikova, I. N., 1963. O predstavitelyach roda Athrotaxis iz Paleogena Kaliningradskoy Oblasti. Paleontol. Zh., 2: 116-125.

DuRAND, S. et REY, R., 1963. Les formations à végétaux de Joursac (Cantal) peuvent être datées du Villafranchien par l'analyse pollinique. Compt. Rend., 257(18): 2692-2693.

Engelhardt, H., 1870. Flora der Braunkohlenformation im Königreich Sachsen. Preisschr. Fürstl. Jablonowski'schen Ges. Leipzig, 16: 1-69.

ENGELHARDT, H., 1902. Uber Tertiärpflanzen von Himmelsberge bei Fulda. Abhandl. Senckenberg. Naturforsch. Ges., 20(3): 248-306.

ENGelhardT, H., 1911a. Uber tertiäre Pflanzenreste von Flörsheim am Main. Abhandl. Senckenberg. Naturforsch. Ges., 29(4): 307-406.

Engelhardt, H., 1911b. Uber tertiäre Pflanzenrestevon Wieseck bei Giessen. Abhandl. Senckenberg. Naturforsch. Ges., 29(5): 407-428.

EngelhaRdT, H. und Kinkelin, F., 1911. I. Oberpliozäne Flora und Fauna des Unter-Maintales in besondere des Frankfurter Klärbeckens. II. Unterdiluviale Flora von Hainstadt am Main. Abhandl. Senckenberg. Naturforsch. Ges., 29(3): 151-306.

FIRTion, F., 1946. Etude pollen-analytique d'un lignite de la formation cinéritique du lac Chambon (Puy-de-Dôme). Bull. Soc. Géol. France, 16: 511-515.

Firtion, F., 1958. Palynologie. In: P. Grangeon (Rédacteur), Contribution al'Étude de la Paléontologie vegétale du Massif du Coiron (Ardèche)-Mém. Soc. Hist. Nat. Auvergne, 6: 273-278.

FLoRIN, R., 1922. On the geological history of the Sciadopitineae. Svensk. Bot. Tidskr., 16 (2).

FLoRIN, R., 1963. The distribution of conifer and taxad genera in time and space. Acta Hort. Berg., 20(4): 121-312.

FlorschüTz, F., 1925. On Pseudolarix kaempferi GoRD. from the clay of Reuver. Rec. Trav. Botan. Neerl., 22: 269-273.

Florschütz, F. and VAN SOMERen, A. M. H., 1950. The palaeobotanical boundary PliocenePleistocene in The Netherlands. Intern. Geol. Congr. 18th, Rept., 9: 40-46.

Follieri, M., 1957. Primi reperti floristici nell' ambiente dell'Elephas dell'Aquila. Ann. Botan., 25: 91-93.

Foldieri, M. et Napoleone, I., 1964. Pollen fossiles dans les argiles marines près de Mazzono (Rome). Rept. 6th Intern. Congr. INQUA, 2: 389-394.

Frantz, U., 1961. Untersuchungen zur Sporen- und Pollen-flora des Pliozän von Willershausen. Monatsber. Deut. Akad. Wiss. Berlin, 3(7/8): 426-442.

Friedrich, P., 1883. Beiträge zur Kenntnis der Tertiärflora der Provinz Sachsen. Abhandl. Geol. Spezialkarte Preussen, 4(3): 443.

GARDNER, J. S., 1886. A monograph of the British Eocene flora. Monograph Palaeontograph. Soc., pp.1-159.

Gaudin, C. T., 1855. Flore fossile des environs de Lausanne. Bull. Soc. Vaudoise Sci. Nat., 4: 422-436.

Gaudin, C. T. et Strozzi, C. M., 1858. Contribution à la flore fossile italienne, 1. Mémoire sur 
quelques gisements de feuilles fossiles en Toscane. Neue Denkschr. Allgem. Schweiz. Ges. Naturwiss., 16: 1-47.

Gaudin, C. T. et Strozzi, C. M., 1860. Contribution à la flore fossile italienne, IV. Neue Denkschr. Allgem. Schweiz. Ges. Naturwiss., 17: 1-30.

Geyler, T. und Kinkelin, F., 1890. Oberpliozänflora aus den Baugruben des Klärbeckens und der Schleuse bei Höchst am Main. Abhandl. Senckenberg. Naturforsch. Ges., 15: 1-47.

Givulescu, R., 1951. La flore fossile de Luncsoara (Bihor). Acad. Rep. Populare Romine, Filiala Cluj, Studii Cercetari Stiint., 2(1): 108-126.

Givulescu, R., 1952. Note paleobotanice, I. Acad. Rep. Populare Romine, Filiala Cluj, Studii Cercetari Stiint., 3(1/2): 131-141.

Grvulescu, R., 1956a. Notă preliminară asupra resultatelor cercetării florei fosile dela Valea Neagră de Criş, reg. Oradea. Comun. Acad. Rep. Populare Romine, 6(4): 577-585.

Givulescu, R., 1956b. Date noi pentru flora tertiarŭ a R.P.R. Comun. Acad. Rep. Populare Romine, 6(10): 1233-1239.

Grvulescu, R., 1960. Neue Untersuchungen über die pflanzenführenden Mergel von Gheghie (Bez. Oradea-Grosswardein, Rumanien). Acta Botan. Acad. Sci. Hung., 6(1/2): 35-44.

Givulescu, R., 1961. Die fossile Flora von Beznea. Neues Jahrb. Geol. Paläontol., 113: 327-350.

Givulescu, R., 1962. Die fossile Flora von Valea Neagiră, Bez. Crişana, Rumäniens. Palaeontographica, $B, 110$ : 128-187.

Givulescu, R. und NicoRicı, E., 1960. Das Sarmat von Fizeş (Rumänien) und seine fossile Flora. Neues Jahrb. Geol. Paläont., 110(2): 180-185.

Glangeand, L. et MarTy, P., 1936. La formation d'âge miocène supérieur de la Bourboule (Puy-de-Dôme). Mém. Soc. Géol. France, 13: 1-50.

Gothan, W. und WeYland, H., 1964. Lehrbuch der Paläobotanik. Akademie Verlag, Berlin, 594 pp.

GrAY, J., 1964. Northwest American Tertiary palynology: the emerging picture. In: L. M. CRANWell (Editor), Ancient Pacific Floras, The Pollen Story. Univ. Hawaii Press, Honolulu, Hawaii, pp. 21-30.

Greguss, P. et VAnhoorne, R., 1964. L'Âge des couches de sable situées entres les argiles de la Campine et le Poederlien en Belgique. Bull. Inst. Roy. Sci. Nat. Belgique, 40(3): 1-6.

Grossheim, V. A. i Gladxova, A. N., 1951. Rezul'taty izucheniya pyl'tsy i spor v Khadumskikh i Maykopskikh sloyakh vostochnogo Predkavkaz'ya. Dokl. Akad. Nauk S.S.S.R., 80: 805-807.

HeER, O., 1855. Flora Tertiariae Helvetiae. Winterthur, 1.

HeEr, O., 1869. Beiträge zur Kreide-Flora, I. Flora von Moletein in Mähren. Neue Denkschr. Allgem. Schweiz. Ges. Naturwiss., 23: 1-24.

Heer, O., 1871. Beiträge zur Kreide-Flora, II. Zur Kreideflora Quedlinburgs. Neue Denkschr. Allgem. Schweiz. Ges. Naturwiss., 24: 1-16.

Helal, A. H., 1958. Das Alter und die Vertreitung der tertiären Braunkohlen bei Bergisch Gladbach östlich von Köln. Fortschr. Geol. Rheinland Westfalen, 2: 419-435.

Holtz, S., 1962. Sporen-stratigraphische Untersuchungen im Oligozän von Hessen. Abhandl. Hess. Landesamtes Bodenforsch., 40: 1-46.

JAblonszky, E., 1915. Die Mediterrane Flora von Tarnóc. Mitt. Jahrb. Kgl. Ungar. Geol. Reichsanst., 22(4): 249-293.

Jahandiea, E. et Maire, R., 1931. Catalogue des Plantes de Maroc. 1: 159 pp.

Johnson, T., 1936. A conifer new to the British Isles Cunninghamia squamata sp. nov. Mem. Proc. Manchester Lit. Phil. Soc., 80: 25-27.

Jux, U., 1960. Zur Geologie des Vopnafjord-Gebietes in Nordost-Island. Geologie, 9(28): 1-57.

KINKeLIN, F., 1900. Beiträge zur Geologie der Umgegend von Frankfurt-a-M, 1. Oberpliocänflora von Niederursel und im Untermainthal. Abhandl. Senckenberg. Naturforsch. Ges., 32: 121-138.

KIrChHeIMER, F., 1934. Úber Tsuga-Pollen aus dem Tertiär. Planta, 22: 171-179.

KIRCHHEIMER, F., 1950. Mikrofossilien aus Salzablagerungen des Tertiärs. Palaeontographica, $B, 90: 127-160$.

KNoвloch, E., 1962. Paleogenní flóra z Ceského Chloumka u Karlových Var. Sb. Ústřed. Ústavú Geol., 27: 101-138. 
Korallova, V. V., 1962. Spore and pollen complexes of the Upper and Middle Miocene of the northern part of the Black Sea area depression. Ukr. Botan. Zh., 19(4): 55-62 (in Ukrainian).

KozYAR, L. A., 1957. Sporovo-pyl'tsevyye kompleksy Khadumskoy svity r. Kubani. Dokl. Akad. Nauk S.S.S.R., 116: 301-303.

Krasnova, A. N., 1910. Nachatki tretichnoi flora Yuga Rossii. Tr. Imp. Char'k Univ., Obshch. Isp. frirody, 44.

KRÄUSEL, R., 1918. Nachträge zur Tertiärflora Schlesiens, 1. Jahrb. Preuss. Geol. Landesanstalt (Berlin), 39(1): 329-417.

KräUSEL, R., 1935. Paläobotanische Notizen, XX. Die Koniferengattung Amentotaxus PILG. im Tertiär der Wetterau. Senckenbergiana Lethaea, 17(3/4): 137-144.

KRÄUSEL, R., 1938. Die tertiäre Flora der Hydrobienkalke von Mainz-Kastel. Paläontol. Z., 20: 9-103.

KRÄUSEL, R., 1940. Die Frankfurter Wälder vor der Eiszeit. Natur Volk, 70: 446-461.

KREMP, G., 1950. Pollenanalytische Untersuchungen des Miozänen Braunkohlenlagers von Konin an der Warthe. Palaeontographica, B, 90: 53-93.

Kryshtofovich, A., 1931. Sarmatskaya flora s r. Krynka. Tr. Gl. Geol. Pazvedochnogo Upravleniya, S.S.S.R., 98: 1-27.

Kryshtofovich, A., 1956. Oligochenovaya flora gora Ashotac v Kazachctane. Palaeobotanica, 1: 1-171.

Laurent, L. et Marty, P., 1905. Flore pliocène des cinérites du Pas-de-la-Mougudo et de SaintVincent-la-Sabie (Cantal). Ann. Muséum Hist. Nat. Marseille, Géol., 9: 1-313.

Laurent, L. et MARTY, P., 1927. Flore pliocène des hautes vallées de la petite Rhue et de la Véronne (Cantal). Ann. Muséum Hist. Nat. Marseille, Géol., 21.

Leroi-Gourhan, A., 1961. Flores quaternaires françaises. Bull. Botan. Soc. France, 108(5/6): 244-254.

LESCHIK, G., 1952. Mikrobotanisch-stratigraphische Untersuchungen der jungpliozänen Braunkohle von Buchenau (Kr. Hünfeld). Palaeontographica, B, 92: 1-51.

LeschiK, G., 1954. Die oberpliozäne Flora von Hünfeld (Hessen). Senckenbergiana Lethaea, 35(3/4): 247-262.

LEschIK, G., 1956. Die Entstehung der Braunkohle der Wetterau und ihre Mikro- und Makroflora. Palaeontographica, B, 100: 26-64.

LI, H.-L., 1952. The genus Amentotaxus. J. Arnold Arboretum (Harvard Univ.), 33(2): 192-198.

LöHNERT, E., 1962. Zur Fazies und Genese pliopleistozäner Braunkohlen Süditaliens. Geol. Rundschau, 51(2): 631-643.

LoNA, F., 1950. Contributi alla storia della vegetazione a del clima nulla Val Padana-analisi pollinica del giacimento Villefranchiano di Leffe (Bergamo). Atti Soc. Ital. Sci. Nat., 89: 123-178.

LoNA, F., 1962. Prime anilisi pollinologiche sui depositi terziari-quaternari di Castell'Arquato: reperti di vegetazione da clima freddo sotto le formazioni calcaree ad Amphistegina. Boll. Soc. Geol. Ital., 81(1): 89-91.

LONA, F. e RicCIARDI, E., 1961 a. Reperti pollinologici nei depositi pleistocenici del bacino lacustre del Mercure (Italia meridionale, region Lucano-Calabra). Pollen Spores, 3(1): 85-92.

LONA, F. e Ricciardi, E., 1961b. Studio pollinologico stratigrafico stu una serie lacustre pleistocenica dell' Italia centrale (Bacino di Gubbio, Perugia). Pollen Spores, 3(1): 93-100.

MACKo, S., 1957. Lower Miocene pollen flora from the Valley of Klodnica near Gliwice (Upper Silesia). Trav. Sac. Sci. Lett., Wroclaw, Sér. B, 88: 1-314.

MAcko, S., 1959. Pollen grains and spores from Miocene brown coals in Lower Silesia, 1. Trav. Soc. Sci. Lett., Wroclaw, Sér. B, 96: 1-160.

MACKo, S., 1963. Sporomorphs from Upper Cretaceous near Opole (Silesia) and from the London Clays. Trav. Soc. Sci. Lett., Wroclaw, Sér. B, 106: 1-82.

MÄDLER, K., 1939. Die pliozäne Flora von Frankfurt am Main. Abhandl. Senckenberg. Naturforsch. Ges., 446: 1-302.

Mägdefrau, K., 1956. Paläobiologie der Pflanzen. Fischer, Jena, 3 Aufl., 443 pp.

MaI, D. H., 1964. Die Mastixioideen-Floren in Tertiär der Oberlausitz. Paläontol. Abhandl. Geol. Ges. D.D.R., 2(1): 1-192. 
Maire, R., Guinochet, M. et Faurel, L., 1952. Flore de l'Afrique du Nord. Lechevalier, Paris, 1: $366 \mathrm{pp}$.

Manten, A. A., 1958. Palynology of the Miocene browncoal mined at Haanrade (Limburg, Netherlands). Acta Botan. Neerl., 7: 445-488.

MarTy, P., 1931. Sur l'âge des plus anciens basaltes de l'Aubrac. Bull. Soc. Géol. France, Sér. 5, 1: 177-188.

Massalongo, A., 1853. Prodromus fiorae fossilis Senogalliensis. Giorn. Ist. Lomb., 5: 197-230.

Massalongo, A. e Scarabelli, G., 1859. Studii sulla Flora Fossile e Geologia del Senigalliense. Galeati, Verona, 509 pp.

Mazancová, M., 1962. Rostlinné mikrofosilie z ložiska Uhelná ve Slezsku. Sb. Ústred. Ústavu. Geol., 27: 159-191.

MENÉNDEZ AMOR, J., 1955. La depresión ceretana española y sus vegetales fósiles. Característica fitopaleontológica del Neogeno de la Cerdaña española. Mem. Real Acad. Cienc. Exac. Fis. Nat., Ser. Cienc. Nat., 18: 1-345.

MenÉndeZ Amor, J. y Florschütz, F., 1959. Algunas noticias sobre el ambiente en que vivió el Hombre durante el gran interglacial en dos zonas de ambas Castillas. Estud. Geol., Inst. Invest. Geol. Lucas Mallada (Madrid), 15: 277-282.

MENÉNDEZ AMOR, J. and FLORSCHÜtZ, F., 1964. Results of the preliminary palynological investigation of samples from a $50 \mathrm{~m}$ boring in southern Spain. Bol. Real Soc. Españ. Hist. Nat., Secc. Geol., 62(2): 251-255.

Meschinelli, A. e SQuinabol, X., 1892. Flora Tertiaria Italica. Padua, 595 pp.

MEYER, B. L., 1956. Mikrofloristische Untersuchungen an jungtertiären Braunkohlen im östlichen Bayern. Geol. Bavarica, 25: 100-128.

MiLAKović, B. B., 1956. Neogena fosilna fora kod Slanaca u Okolini Beogradu. Glaznik Prirod. Muzeja Srpske Zemlje, Ser. A, 7(3): 189-204.

MiLAKović, B. B., 1960. O palinološkim prončavanjima u ugljonosnom neogenu kraljevačkoCačanskog Basena. Glasnik Prirod. Muzeja Srpske Zemlje, Ser. A, 13: 41-48.

MiLAKović, B. B., 1961. O stratigrafskom značaju polena i spora iz ugljonosne serije papratiške reke kod Užicke Požege. Glasnik Prirod. Muzeja Srpske Zemlje, Ser. A, 14: 45-54.

Miller, J. A. and Harland, W. B., 1963. Ages of some Tertiary intrusive rocks in Arran. Mineral. Mag., 33: 521-523.

Müller-Stoll, W. R., 1936. Zur Kenntnis der Tertiärflora der Rhön. Beitr. Naturk. Forsch. Südwest Deut., 1(1): 89-128.

MülleR-STOLL, W. R., 1938. Die jüngsttertiäre Flora des Eisensteins von Dernbach (Westerwald). Botan. Zentr., Beih., B, 58: 376-434.

MURACHOvSKaYA, E. I., 1956. O vozraste i stratigraficheskom raschlenenii uglenosnoy tolshchi Maykubenskogo basseina. Izv. Akad. Nauk Kaz. S.S.R., Ser. Geol., 24: 59-73.

NAGY, E. 1959. Pollenanalytische Untersuchungen einer Ungarischen Pliozänen Braunkohle. Acta Botan. Acad. Sci. Hung., 5: 413-423.

NAGY, E., 1962. New pollen species from the Lower Miocene of the Bakony Mountain (Varpalota) of Hungary. Acta Botan. Acad. Sci. Hung., 8(1/2): 153-163.

Nonn, H. y Medus, J., 1963. Primeros resultados geomorfologicos y palinologicos referentes a la cuenca de Puentes de Garcia Rodriguez (Galicia). Notas Commun. Inst. Geol. Minero España, 71: 87-94.

OldFIELd, F., 1962. Quaternary plant records from the Pays Basque, 1. Le Moura, Mouligna, Marbella. Bull. Centre Etudes Rech. Sci. Biarritz, 4(2): 211-217.

Oszast, J., 1960. Analisa pylkowa ilow tortonskich ze Starych Gliwic. Monograph. Botan., 9(1): $1-47$.

Pacltová, B., 1958. Palynologický výzkum terciéru v oblasti Handlová na Slovensku. Casopis Mineral. Geol., 3(3): 289-300.

Pacltová, B., 1963. Palynologická charakteristika ledenického souvrství (svrchní pliocén) v Třeboňské panvi v jižních Cechách. Sb. Geol. Ved. Paleontol., Sect. P, 2: 7-55.

Pacltová, B. i ŽERT, B., 1958. Oligomiocenné pylové společenstvo v nadloži čedičového výlenu v chebské pánvi. Věstn. Ústřed. Ústavu Geol., 33(5): 350-353.

Paganelli, A., 1960. Primi saggi per uno studio pollinologico del deposito lignifero di Pietrafitta (Umbria). Nuovo Giorn. Botan. Ital., 67(3/4): 601-605. 
Paganelli, A., 1962. Rinvenimento del polline di Keteleeria in alcuni depositi quaternari dell' Italia centro-settentrionale. Nuovo Giorn. Botan. Ital., 69(1/3): 103-108.

Pálfalvy, I., 1951. Növénymaradványok Eger harmad idöszakából. Földt. Közl., 81(1/3): 57-80.

Palibin, J., 1901. Quelques données relatives aux débris végétaux contenus dans les sables blancs et les grès quartzeux de la Russie méridionale. Bull. Commun. Géol., 20: 447.

Pantić, N. K., 1958. Die fossile Flora in den weissen Bauxiten von Montenegro (Jugoslavien). Ann. Géol. Péninsule Balkan., 25: 77-83.

Pantić, N. K. and Beslagic, A., 1964. Palynological analysis of the lignites in the Tertiary of the Livno valley. Geol. An. Balkansk Palvostr. Jugosl., 31: 127-134 (in Serbo-Croatian).

Pantić, N. K. and Nicolić, V., 1956. A supplement to our knowledge of the Pliocene flora of Macedonia. Bull. Inst. Géol. Rép. Macédonienne, 5: 69-110 (in Macedonian).

Paolucci, L., 1896. Nuovi Materiali e Richerche Critiche sulle Piante Fossili Terziarie dei Gessi d'Ancona. Ancona.

Papulov, G. N. and Bronnikova, N. J., 1963. On the Lower Cretaceous flora in the middle Urals. Tr. Gorno-Geol. Inst., Akad. Nauk S.S.S.R., Ural Fil., 61: 95-100 (in Russian).

Peola, P., 1899. Florula messiniana di Monte Castello d'Alessandria. Boll. Soc. Geol. Ital., 18.

Pflug, H., 1956. Sporen und pollen von Tröllatunga (Island) und ihre Stellung zu den pollenstratigraphischen Bildern Mitteleuropas. Neues Jahrb. Geol. Paläontol., 102(3): 409-430.

Pflug, H., 1959. Sporenbilder aus Island und ihre stratigraphische Deutung. Neues Jahrb. Geol. Paläontol., 107(2): 141-172.

Planderová, E., 1963. Palynologický výskum modrokamenskej Uhol'nej Panvy. Geol. Práce, Zpravy, 30: 189-208.

Pokrovskaya, 1. M. i Stel'MaK, N. K. (Editors), 1964. Atlas nizhnemelovach sporovo-pal'tsevach kompleksov nekotorach Rayonov S.S.S.R. Tr. Gos. Geol. Kom., S.S.S.R., 124: 1-408.

Pons, A., 1964. Contribution palynologique à l'étude de la flore et végétation pliocènes de la region rhodanienne. Ann. Sci. Nat., Botan. Sér. 12, 5(3): 499-722.

Post, G. E. and Dinsmore, T. E., 1932. Flora of Syria, Palestine and Sinai. American Univ., Beirut, 2nd ed., 1: 658 pp.

Potoní, R., Thomson, P. W. und Thiergart, F., 1950. Zur Nomenklatur und Klassifikation der neogenen Sporomorphae (Pollen und Sporen). Geol. Jahrb., 65: 35-70.

PrinciPI, P., 1926. La fiora oligocenica di Chiavon e Salcedo. Mem. Serv. Descriz. Carta Geol. Italia, 10: 1-130.

PURI, G. S., 1957. Preliminary observations on the phyto-geographical changes in the Kashmir Valley during the Pleistocene. Palaeobotanist, 6(1): 16-18.

Quezel, P., 1960. Flore et palynologie sahariennes. Quelques aspects de leur signification biogéographique et paléoclimatique. Bull. Inst. Franç. Afrique Noire, Sér. A (Sénégal), 22(2): 353-360.

RÁsKy, K., 1958. Die obermiozäne Flora von Tállya (Ober-Ungarn); vorläufiger Bericht auf Grund der Revision der durch neuere Einsammlung bereichterten obermiozänen Flora von Tállya. Paläontol. Z., 32(3/4): 181-189.

Rasmussen, J. and KoCH, E., 1963. Fossil Metasequoia from Mikines, Faroe Islands. Ann. Soc. Sci. Faeroensis, 12: 83-96.

REID, C. and Reid, E. M., 1915. The Pliocene floras of the Dutch-Prussian border. Mededeel. Rijksopsporingsdienst Delfstoffen, 6: 1-176.

Ricciard, E., 1964. Über die Altersbestimmung des Braunkohlenbeckens Mercure (Süditalien). Geol. Rundschau, 53(2): 866-870.

RudolPH, K., 1936. Mikrofossilische Untersuchung tertiärer Ablagerungen im nördlichen Böhmen. Botan. Zentr., Beih., B, 54: 244-328.

SAMUEL, O. a SNOPKovÁ, P., 1962. Mikrobiostratigrafické a palynologické korelačné štúdiá centrálnokarpatského Paleogénu. Geol. Práce Zpravy, 63: 69-84.

Schloemer-JÄGer, A., 1958. Alttertiäre Pflanzen aus Flözen der Brögger-Halbinsel Spitzbergens. Palaeontographica, B, 104(1/3): 39-103.

SCHLOEMER-JÄGER, A., 1959. Keine Funde von Metasequoia-Zapfen in der Braunkohle von Düren und Zülpich im Rheinland. Palaeontographica, B, 105(5/6): 158-159.

SCHLOEMER-JÄGER, A., 1960. Koniferen-Zapfen aus der niederrheinischen Braunkohle. Senckenbergiana Lethaea, 41: 209-253. 
SCHÖNFELD, E., 1956. Metasequoia in der Westdeutschen Braunkohle. Senckenbergiana Lethaea, 36(5/6): 389-399.

Schulze, E., 1887. Uber die Flora der subhercynischen Kreide. $Z$. Naturwiss., 60: 440-470.

SERCEL, A., 1961. The Lower Pleistocene vegetation from Zalog near Novo Mesto. Sloven. Akad. Znanosti Umetnosti, Razred Prirod. Medic. Vede Razprave, 6: 417-434 (in Serbo-Croat.).

SERCEL, A., 1965. Lower Pleistocene flora from Bukovica near Ilirska Bistrica. Slovan. Akad. Znanosti Umetnosti, Razred Prirod. Medic. Vede Razprave, 8: 439-470 (in Serbo-Croat.).

Seward, A. C., 1919. Fossil Plants. Cambridge Univ. Press, London, 4: 543 pp.

Shatilova, I. I., 1962. Variations that occurred in the flora of Guria in the Kuyalnitzky age according to data secured by spore-pollen analysis. Dokl. Akad. Nauk. S.S.S.R., 145(4): 895-898 (in Russian).

ShCHEkINA, N., 1956. Materialy do flory druhoho seredzemnomors'koho yarusu L-vivs'koyi oblasti. Ukr. Botan. Zh., 13(3): 41-48.

ShCheKINA, N., 1957. Resul'taty sporovo-pylkovykh doslidzhen buroho buhillya L'vis'koyi ta Stanislavs'koyi oblasteyi. Ukr. Botan. Zh., 14(2): 36-43.

ShChekina, N., 1958. Results of spore and pollen investigations of the Palaeogene deposits of the Zvenigorodka District, Cherkassy Region. Ukr. Botan. Zh., 15(3): 54-59 (in Ukrainian).

ShCheKINA, N., 1962. Flora of the brown coal and carbonaceous clays from the lower part of the Poltava Suite in the environs of Kiev, according to data of spore and pollen analysis. $U \mathbf{k r}$. Botan. Zh., 19(2): 62-85 (in Ukrainian).

Simpson, J. B., 1961. The Tertiary pollen flora of Mull and Ardnamurchan. Trans, Roy Soc. Edinburgh, 64: 421-476.

SismondA, E., 1865. Matériaux pour servir à la paléontologie du terrain tertiaire du Piémont. Mém. Acad. Torino, 22(4): 391-471.

SnOPKovA, P., 1960. Palynologický výskum panónskych súvrstvi z okolia Nitry. Geol. Práce Zpravy, 20: 189-195.

SNOPKovA, P., 1961. Palynologický výskum neogénnych sedimentov z okolia Stúrova, Nových Zámkov a Povăzia. Geol. Práce Zpravy, 23: 215-231.

SORDELli, F., 1896. Studi sulla Vegetazione di Lombardia. Milano.

Squinabol, S., 1891. Contribuzioni alla Flora Fossile dei Terreni Terziarii della Liguria. Gênes.

StachurSKA, A., 1960. Keteleeria w osadach interglicjalnych z Suszna nad Bugiem. Przeglad Geol., 8(5): 283.

Staub, M., 1885. Pinus palaeostrobus EtTrNo. in der fossilen Flora Ungarns. Természetrajzi Füzetek, 9: 47.

Stefanoff, B., 1930. Une reste fossile de Pseudotsuga spéc. dans les couches pliocènes près du village de Kuido. Z. Bulg. Geol. Ges., 2: 105-109.

Stockmans, F., 1936. Végétaux éocènes des environs de Bruxelles. Mém. Musée Roy. Hist. Nat. Belg., 76: 1-56.

Stojanoff, N. und Stefanoff, B., 1929. Beitrag zur Kenntnis der Pliozänflora der Ebene von Sofia. Z. Bulg. Geol. Ges., 2(3): 113 pp.

Straus, A., 1952. Beiträge zur Pliozänflora von Willershausen, III. Die niederen Pflanzengruppen bis zu den Gymnospermen. Palaeontographica, B, 93: 1-44.

SuPrunOVA, N. I. i VRoNsKI, V. A., 1965. K biostratigrafii verchnepliotsenovach i chetvertichnach otlozhenii yugo-zapadnoi chasti Astrachanskoi oblasti. Dokl. Akad. Nauk S.S.S.R., 161(1): 191-198.

Svechnikova, I. N., 1953. Nachodka roda Cryptomeria DoN. v Meoticheskich Otlozheniyach Grozii. Dokl. Akad. Nauk. S.S.S.R., 92(2): 417-419.

Svechnikova, I. N., 1963. Atlas and key for the identification of the living and fossil Sciadopityaceae and Taxodiaceae based on the structure of the leaf epiderm. Palaeobotanica, 4: 205-229 (in Russian with English summary).

Svechnikova, I. N., 1964. Predstavitel' roda Cathaya (Pinacea) iz Pliotsena Abchazii. Paleontol. Zh., 2: 125-131.

Svechnikova, I. N. and Bydantsev, L. J., 1959. The Tertiary flora of the Kaliningrad Peninsula. Botan. $Z h$., 44(2): 211-214 (in Russian).

Szafer, W., 1949. Studies on the genus Tsuga Carr. in the Tertiary of Europe. Bull. Acad. Polon. Sci. Lett., Cl. Sci. Math. Nat., Sér. B, Sci. Nat., 1949: 23-51. 
Szafer, W., 1954. Pliocenska flora okolic Czorsztyna i jej stosunek do plejstocenu. Inst. Geol. Prace, 11: 1-238.

Szafer, W., 1958. The genus Cunninghamia R. BR. in the European Miocene. Acta Biol. Cracoviensia, Ser. Botan., 1: 7-13.

SzAFER, W., 1961. Miocénska flora ze Starych Gliwic na Slasku. Inst. Geol. Prace, 33: 1-205.

Teixeira, C., 1945. Pinheiro fossil do Pliocénico de Rio-Maior. Bol. Soc. Broteriana, Ser. 2, 19: 201-205.

Teslenko, I. V., 1959. A contribution to the study of the Miocene flora of the maritime area to the north of the Sea of Azov. Botan. Zh., 44(1): 64-74 (in Russian).

Thiergart, F., 1958. Die Sporomorphen-Flora von Rott im Siebengebirge. Fortschr. Geol. Rheinland Westfalen, 2: 447-456.

Thomson, P. W. und Pflug, H., 1953. Pollen und Sporen des mitteleuropäischen Tertiärs: Gesamtübersicht über die stratigraphisch und paläontologisch wichtigen Formen. Palaeontographica, $B, 94:$ 1-138.

Thomson, P. W. und ReIN, U., 1950. Mikropaläontologische Untersuchung eines Standardprofils der rheinischen Braunkohle in der Grube Liblar/Bezirk Köln. Geol. Jahrb., 65: 107-112.

Unger, F., 1847. Chloris Protogaea. Leipzig, 150 pp.

UNGER, F., 1867. Die fossile Flora von Kumi auf der Insel Euboea. Denkschr. Kaiserl. Akad. Wiss., Math. Naturw. Cl., 27: 27-93.

Vanhoorne, R., 1963. La superposition des Sables de Mol et des Argiles de la Campine. Mém. Soc. Belge Géol. Paléontol. Hydrol., 6: 83-94.

VeLENovsKÝ, J., 1881. Die Flora aus den ausgebrannten tertiären Letten von Vrsoviĉ bei Laun. Abhandl. Kaiserl. Böhm. Ges. Wiss., Ser. 6, 11(1): 1-156.

Vishinu-MitTre, Singh, G. and SAKSENA, K. M. S., 1963. Pollen-analytical investigations of the Lower Karewas. Palaeobotanist, 11(1-2): 92-95.

Von der Brelie, G., 1958. Sporen und Pollen im marinen Tertiär der Niederrheinischen Bucht. Fortschr. Geol. Rheinland Westfalen, 1: 185-204.

Von Der Brelie, G. und Wolters, R., 1958. Das Alttertiär von Gürzenich. Fortschr. Geol. Rheinland Westfalen, 2: 473-477.

Von Ettingshausen, C., 1851a. Die Tertiär-Floren der Österreichischen Monarchie, 1. Fossile Flora von Wien. Abhandl. Kaiserl. Königl. Geol. Reichsanstalt., 2: 1-36.

Von Ettingshausen, C., 1851b. Die Tertiäre Flora von Häring in Tirol. Abhandl. Kaiserl. Königl. Geol. Reichsanstalt., 2: 1-118.

Von Ettingshausen, C., 1853. Beiträge zur Kenntnis der fossilen Flora von Tokaj. Sitz. Ber. Kaiserl. Akad. Wiss., Math. Naturw. Cl., 11(4): 779-861.

Von Ettingshausen, C., 1868. Die fossile Flora der älteren Braunkohlenformation der Wetterau. Sitzber. Kaiserl. Akad. Wiss., Math. Naturw. Cl., 57: 807.

Von Ettingshausen, C., 1872. Die fossile Flora von Sagor in Krain, 1. Denkschr. Kaiserl. Akad. Wiss., Math. Naturw. Cl., 32: 159-202.

Von EtTIngshausen, C., 1890. Die fossile Flora von Schoenegg bei Wies in Steiermark. Denkschr. Kaiserl. Akad. Wiss., Math. Naturw. Cl., 57: 61-112.

VRONSKII, V. A., 1963. The results of the palynological analysis of Quaternary and Upper Pliocene deposits near Zelma village (Astrakhan region). Dokl. Akad. Nauk S.S.S.R., 152(4): 934-936 (in Russian).

Watelet, A., 1866. Description des Plantes Fossiles du Bassin de Paris, Ballière, Paris, 264 pp.

Weyland, H. und Pflug, H., 1957. Die Pflanzenreste der pliozänen Braunkohle von Ptolemaîs in Nordgriechenland, 1. Palaeontographica, B, 102: 96-108.

Weyland, H., Pflug, H. und Pantić, N., 1958. Untersuchungen über die Sporen- und PollenFlora einiger Jugoslawischer und griechischer Braunkohlen. Palaeontographica, B, 105: 75-99.

Weyland, H., Pflug, H. und Müller, H., 1960. Die Pflanzenreste der pliozänen Braunkohle von Ptolemaĩs in Nordgriechenland, II. Palaeontographica, B, 106: 71-98.

Woldstedt, P., 1958. Das Eiszeitalter. Grundlinien einer Geologie des Diluviums. Enke, Stuttgart, 2:438 S.

WoLfF, H., 1934. Mikrofossilien des pliocanen Humodils der Grube Freigericht bei Dettingen 
a.M. und Vergleich mit älteren Schichten des Tertiärs sowie post-tertiären Ablagerungen. Arb. Inst. Paläobotan. Petrog. Brennstein, 5: 55-86.

ZABLOCKI, J., 1928. Tertiäre Flora von Salzlagers von Wieliczka, 1. Acta Soc. Botan. Polon., 5(2): $174-208$.

ZABlocki, J., 1930. Tertiäre Flora des Salzlagers von Wieliczka, 2. Acta Soc. Botan. Polon., 7(2): 139-156.

ZAGWIJN, W. H., 1959. Zur stratigraphischen und pollenanalytischen Gliederung der pliozänen Ablagerungen im Roertal-Graben und Venloer Graben der Niederlande. Fortschr. Geol. Rheinland Westfalen, 4: 5-26.

ZaGwIJ, W. H., 1960. Aspects of the Pliocene and Early Pleistocene vegetation in The Netherlands. Mededel. Geol. Sticht., Ser. C, 5: 1-78.

ZaKLINSKAYA, E. D., 1953. Opisaniye nekotorykh vidov pyl'tsy i spor vydelennykh iz tretichnykh otlozheniy Pasekovskogo Kar'yeva Voronezhskoy oblasti. Tr. Inst. Geol. Nauk, Akad. Nauk. S.S.S.R., 59: 60-115.

Zalewska, Z., 1959. Flora kopalna Turowa kolo Bogatyni. Prace Muzeum Ziemi, 3: 1-128.

Zalewska, Z., 1961. Pinaceae. In: Flora kopalna Turowa kolo Bogatnyni. Prace Muzeum Ziemi, 4: 24-29.

ZeIDLer, H., 1938. Pflanzenreste aus der obermiozänen Braunkohle von Viehhausen bei Regensburg. Palaeontographica, $B, 83:$ 196-211.

Zharkova, R. A., 1961. New point of extension of the continental Upper Jurassic and Lower Cretaceous in the central Transurals. Tr. Inst. Gorno-Geol., Akad. Nauk S.S.S.R., Ural Fil., 61: 101-105 (in Russian). 